Maria Lucinda Meirelles Aguiar

\title{
ORGANIZAÇÃO E DISPONIBILIZAÇÃO DE BASES DE INFORMAÇÕES MUNICIPAIS PARA GESTÃO DE POLÍTICAS PÚBLICAS
}

\begin{abstract}
Dissertação apresentada à Escola de Comunicação e Artes da Universidade de São Paulo, como exigência parcial para obtenção do Título de Mestre em Ciência da Informação, Programa de Pós-Graduação em Ciência da Informação, Área de Concentração Cultura e Informação, Linha de Pesquisa Acesso à Informação.
\end{abstract}

Orientadora: Profa. Dra. Marilda Lopes Ginez de Lara

\section{São Paulo}


São Paulo, 


\section{AGRADECIMENTOS}

À amiga e orientadora Prof ${ }^{a}$ Marilda Lopes Ginez de Lara pela sua dedicação, incentivo e confiança no potencial deste trabalho.

Às amigas Silvia Rocha e Joice pelo companheirismo e incentivo nesta empreitada conjunta, além da colaboração nos momentos difíceis.

Aos professores do Programa de Pós-Graduação Ciência da Informação e, em especial, as professoras Asa Fujimo e Anna Maria Marques Cintra pelas observações fundamentais no exame de qualificação.

A todos os amigos da Fundação Seade que me ajudaram, em especial a Muga, Amay e Neuma pelo apoio; Osvaldo, Roberto Bernades, Vânia e Silvia Filinto pela colaboração.

Aos meus filhos, Flávio e Caio, pelo apoio e compreensão e aos quais dedico este trabalho. 


\section{RESUMO}

AGUIAR, M. L. Meirelles. Organização e Disponobilização de Bases de Informações Municipais para Gestão de Políticas Públicas. São Paulo, 2006. 81 p. Dissertação (Mestrado em Ciência da Informação) - Escola de Comunicações e Artes, Universidade de São Paulo.

Análise sobre a estrutura e a organização da base de informações institucionais e estatísticas da Pesquisa Municipal Unificada - PMU, sob a perspectiva da disponibilização de seus dados. As informações institucionais e estatísticas, em âmbito municipal, constituem importante subsídio para a gestão pública, devendo ser disseminadas aos executores dos setores governamentais, bem como aos representantes da sociedade civil organizada. Assim, são avaliados os processos de comunicação em sistemas informacionais e os referenciais para organização e tratamento das informações. Procura-se mostrar que o uso de procedimentos documentários e terminológicos pode melhorar as formas de disponibilização, o acesso e a apropriação da informação, concluindo-se que esses princípios devem ser incorporados às políticas de informação institucionais, como meio de otimizar a disponibilização e a recuperação das informações.

Palavras-Chave: sistemas de informação; informação institucional; organização da informação; recuperação da informação; pesquisa municipal; gestão pública; política de informação. 


\section{ABSTRACT}

AGUIAR, M. L. Meirelles. Organization and Availability of Muncipal Data Bases for Management of Public. - Escola de Comunicações e Artes, Universidade de São Paulo (School of Communication and Arts of the University of São Paulo)

Analysis of the structure and organization of the data systems of the institutional and statistical data of the Unified Municipal Research (PMU), from the perspective of the availability of its data. Institutional and statistical data, in that concerning the municipality, provides vital assistance in the administration of public affairs and should be disseminated among administrators of government bodies, as well as representatives of organized civil society. Communication in information systems and the references for their organization and handling are thus evaluated. What is sought is to show that the use of documentary and terminological procedures can improve the means of data availability, as well as the accessing and appropriation of data. This leads to the conclusion that such principles should be incorporated into institutional information policies as a means to optimize data availability and recovery.

Keywords: data systems, institutional data, information organization, data recovery, government management, information policy. 


\section{RELAÇÃO DE FIGURAS}

FIGURA 1 - Tela do questionário de Saneamento Básico - Bloco sobre Administração - PMU 99

FIGURA 2 - Tela do produto Pesquisa Municipal Unificada disponibilizado no site www.seade.gov.br - Seleção do tema Saneamento Básico e do assunto Administração. 49

FIGURA 3 - Tela do produto Pesquisa Municipal Unificada disponibilizado no site www.seade.gov.br - Seleção das variáveis relativas à natureza jurídica das empresas operadoras dos sistemas de abastecimento de água e esgoto sanitário. 50

FIGURA 4 - Tela do produto Pesquisa Municipal Unificada disponibilizado no site www.seade.gov.br - Seleção da abrangência geográfica município

FIGURA 5 - Resultado da busca de informações sobre a natureza jurídica da empresa operadora do sistema de saneamento básico do Município de Campinas no site da Fundação Seade

FIGURA 6 - Tela do Suplemento de Meio Ambiente - Bloco sobre Agenda 21

MUNIC 2002 56

FIGURA 7 - Informações sobre o subtema Agenda 21 agregadas por Unidades da Federação e disponibilizadas no site "Perfil dos Municípios Brasileiros" do IBGE 56

FIGURA 8 - Informações georreferenciadas sobre o subtema Agenda 21 e disponibilizadas no site "Perfil dos Municípios Brasileiros" do IBGE

FIGURA 9 - Informações sobre o subtema Agenda 21 organizadas em tabela Excel e disponibilizadas no site "Perfil dos Municípios Brasileiros" do IBGE

FIGURA 10 - Resultado da busca de informações sobre o subtema Agenda 21 para o Município de Campinas no site "Perfil dos Municípios Brasileiros" do IBGE. 


\section{RELAÇÃO DE QUADROS}

QUADRO 1 - ESTRUTURA DE ORGANIZAÇÃO ..................................... 65

QUADRO 2 - RECUPERAÇÃO POR TEMA ............................................... 69

QUADRO 3 - RECUPERAÇÃO POR ASSUNTO ….................................. 72

\section{RELAÇÃO DE SIGLAS}

PMU - Pesquisa Municipal Unificada

Fundação Seade - Fundação Sistema Estadual de Análise de Dados

LD - Linguagem Documentária

IBGE - Instituto Brasileiro de Geografia e Estatística

PNAD - Pesquisa Nacional de Amostra de Domicílios

IDH - Índice de Desenvolvimento Humano

RAIS - Relação Anual de Informações Sociais

CAGED - Cadastro Geral de Empregados e Desempregados

CDS - Comissão de Desenvolvimento Sustentável das Nações Unidas

MUNIC - Pesquisa de Informações Básicas Municipais

PAEP - Pesquisa da Atividade Econômica Paulista 


\section{APRESENTAÇÃO}

A experiência no desenvolvimento de metodologias de pesquisas institucionais, incluindo a definição dos conceitos das variáveis pesquisadas, a coordenação da etapa de coleta dos dados e a montagem de banco de dados, mostra que, por falta de instrumentos e mecanismos de organização de bancos de dados, a forma de acesso e a utilização da informação pelo usuário são precárias.

Por outro lado, é crescente a carência dos governos municipais por informações sistematizadas para a gestão das políticas públicas. A descentralização das políticas sociais e dos serviços públicos favoreceu o crescimento do poder local e a participação da sociedade civil na tomada de decisão. Neste sentido, foi acentuada a função social da informação estatística, bem como ampliada a demanda por informações mais desagregadas, com abrangência local.

São avaliados os processos de comunicação em sistemas informacionais e identificados os referenciais para organização e tratamento das informações. Também verificam-se os procedimentos de produção das informações, bem como os principais agentes produtores, as fontes de dados, as metodologias de pesquisa e os usuários.

Neste contexto, são realizados estudos sobre a estrutura e a organização de base de informações institucionais e estatísticas, obtidas através de pesquisas municipais, e os procedimentos para sua disseminação. Os processos de tratamento das informações são analisados, bem como a formatação dos produtos para disponibilização e os mecanismos de recuperação dos dados, com o objetivo de propiciar a melhoria do uso da informação para a gestão de políticas públicas.

É neste cenário que se cogita trabalhar, no sentido de compreender os processos de transmissão e uso de informações institucionais e estatísticas, realizando uma análise fundamentada no entendimento de como os autores abordam o problema e, posteriormente, avaliando, através da investigação do 
objeto concreto de estudo, as hipóteses de trabalho a fim de contribuir para a otimização do acesso e uso das informações pela sociedade.

Nos capítulos iniciais procura-se estruturar e delimitar o projeto, definindo-se os objetivos gerais e específicos e identificando os pressupostos sobre os quais se deve trabalhar e os procedimentos metodológicos para desenvolvimento do projeto.

Em seguida, propõe-se o quadro teórico da pesquisa para embasar as análises e proposições quanto aos procedimentos de tratamento e organização das informações para disponibilização. Buscam-se também, referências para a análise dos processos de produção da informação institucional e estatística, bem como para o entendimento das relações produção / usuários e oferta / demanda.

$\mathrm{Na}$ seqüência, são apresentados os procedimentos metodológicos para aplicação da Pesquisa Municipal Unificada - objeto concreto deste estudo - e os processos de produção e divulgação das informações coletadas.

Neste sentido, é avaliada a importância de se incorporar às políticas de disponibilização das informações institucionais a implementação de instrumentos e mecanismos de organização de sistemas de informações, tendo em vista sua recuperação e utilização por diferentes usuários. 


\section{SUMÁRIO}

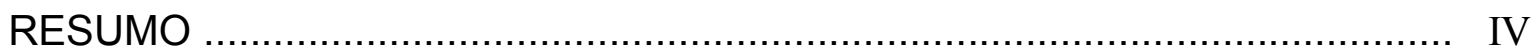

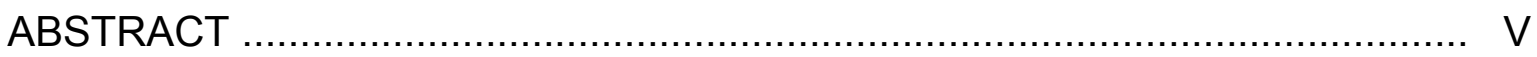

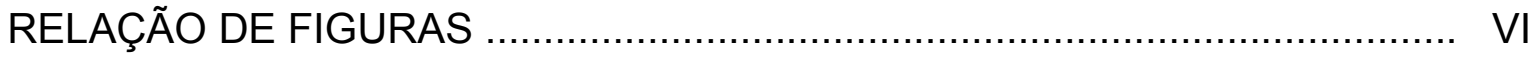

RELAÇÃO DE QUADROS ..............................................................

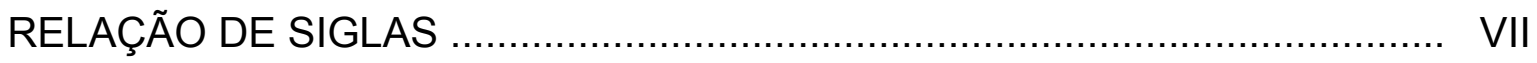

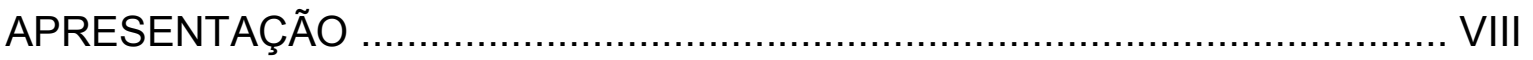

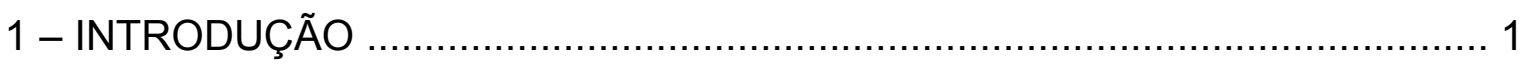

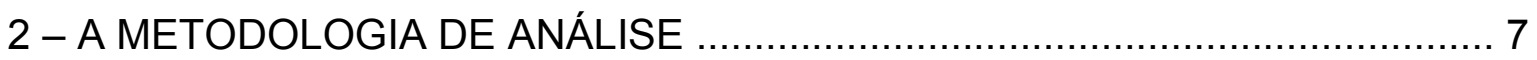

3 - QUADRO TEÓRICO DE PESQUISA ................................................ 9

3.1 - Informação e comunicação ......................................................... 9

3.2 - Organização e tratamento da Informação

3.2.1 - A linguagem documentária ........................................... 15

3.2 .2 - A terminologia ............................................................. 20

3.3 - Informação administrativa como fonte para informação estatística .... 23

3.3.1 - A produção da informação estatística

3.3.1.1 - Agentes - institutos de pesquisas socioeconômicas .... 24

3.3.1.2 - Fontes de coleta de informações ........................... 27

3.3.1.3 - Metodologia de produção de informação .................... 29

3.3.1.4 - Produtos de informações socioeconômicas ................. 31

3.3.2 - O usuário das informações socioeconômicas ........................ 33

3.3.3 - A relação produção / usuário: oferta e demanda ................... 36

4 - A PESQUISA MUNICIPAL UNIFICADA - PMU

4.1 - O contexto da pesquisa ........................................................ 39

4.2 - A etapa de planejamento da pesquisa ..................................... 41

4.3 - A etapa de coleta dos dados .................................................. 43

4.4 - A etapa de disponibilização das informações .................................. 44 
5 - PESQUISAS MUNICIPAIS - DISPONIBILIZAÇÃO E RECUPERAÇÃO DOS RESULTADOS. 45

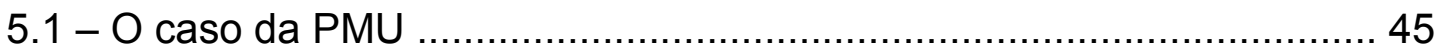

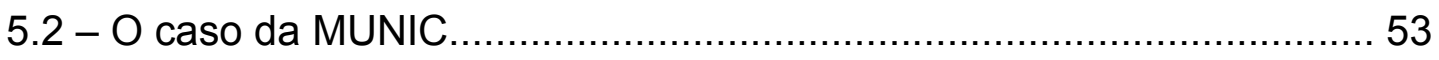

6 - A DISPONIBILIZAÇÃO DA INFORMAÇÃO SEGUNDO PARÂMETROS

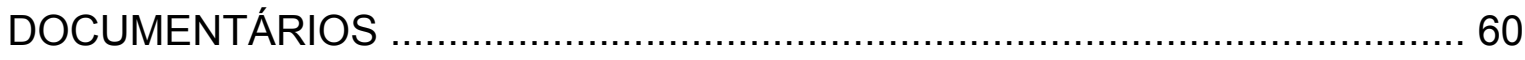

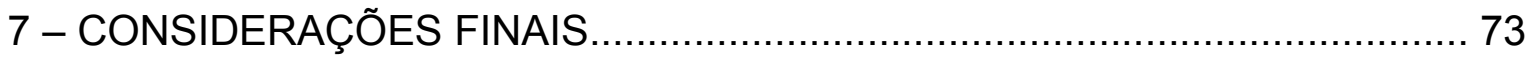

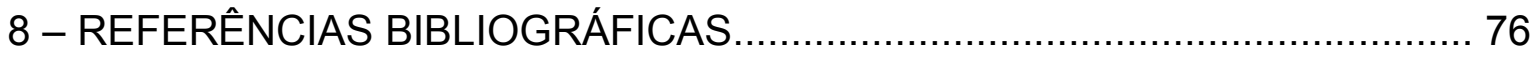

9 - ANEXO - Questionário de Saneamento Básico / PMU 2003 ......................... 80 


\section{1- INTRODUÇÃO}

O objetivo geral deste trabalho é desenvolver um estudo a respeito da estrutura e organização de base de informações institucionais e estatísticas, obtidas através de pesquisas municipais, e dos processos de disponibilização e formatação dos produtos, com o objetivo de contribuir para o tratamento e a melhoria do uso da informação para a gestão de políticas públicas municipais.

Para tanto, pretende-se verificar como as informações coletadas são tratadas e organizadas para disponibilização, identificar a existência de problemas para seu uso, através de parâmetros de organização e uso, e propor formas de a reorganização de produtos para divulgação.

Como resultado final, espera-se contribuir para a discussão de critérios a serem observados no tratamento e na estruturação de base de informações institucionais e estatísticas para disseminação, bem como verificar os procedimentos de organização de produtos para divulgação dos resultados, viabilizando, a partir de uma hipótese de organização das informações e de estrutura de produto, a otimização do acesso e uso das informações pela sociedade.

Parte-se do pressuposto de que a potencialização da divulgação da produção de informações institucionais e estatísticas depende de procedimentos de organização dos dados, baseados, simultaneamente, nas metodologias de construção de linguagens de organização da informação e nas metodologias terminológicas.

Considerando as características dos produtos - bases de informações institucionais e estatísticas - disponibilizados pelos institutos governamentais, entende-se que os procedimentos de tratamento das informações influem na otimização das formas de acesso e utilização, possibilitando, portanto, a potencialização de seu uso.

Entre as formas de disseminação, um dos requisitos para atender aos diferentes usuários é a disponibilização de dados em níveis mais desagregados, permitindo a construção de diferentes cenários ou o desenho de produtos de acordo com suas necessidades. No caso de pesquisas institucionais, trabalha-se 
com a hipótese de que é fundamental que a disponibilização de informações inclua a divulgação da metodologia da pesquisa não só para a compreensão do contexto de sua realização, mas também para possibilitar o confronto com dados de outras bases institucionais. As referências metodológicas e os conceitos das variáveis pesquisadas permitem maior diversificação na elaboração de estudos analíticos e na formulação de indicadores sociais.

A observação de produtos desse gênero mostra que nem sempre são considerados os aspectos relevantes de organização e tratamento das informações na apresentação dos resultados da pesquisa. Entre os vários tipos de produtos que disponibilizam base de dados institucionais e informação estatística sobre os municípios, é analisada, neste trabalho, a Pesquisa Municipal Unificada - PMU, desenvolvida pela Fundação Seade.

Verifica-se que a forma atual de divulgação das informações coletadas pela PMU dificulta a recuperação e o uso das informações para a tomada de decisões na gestão das políticas públicas. Os resultados da pesquisa são apresentados na mesma estrutura do instrumento de coleta utilizado para sua aplicação, não considerando as diferenças existentes entre as funções do levantamento de dados e da disponibilização e recuperação.

O instrumento de coleta objetiva captar as informações sobre a estrutura organizacional das prefeituras, garantir a mais ampla cobertura da pesquisa junto aos municípios paulistas e agilizar o processo de coleta. Por sua vez, os produtos de disseminação dos resultados da pesquisa deveriam obedecer a critérios específicos, no sentido de otimizar o acesso, criando um ambiente propício à recuperação da informação.

Este trabalho, portanto, se justifica pela necessidade de identificar parâmetros para potencializar o uso de informações institucionais pelos seus principais públicos

De fato, se as informações socioeconômicas e as estatísticas públicas já eram consideradas instrumentos fundamentais para a gestão das políticas públicas, atualmente, a demanda por informações é cada vez mais crescente e diversificada. Observam-se, contemporaneamente, a implementação de novas 
políticas públicas que solicitam diferentes informações e novos indicadores, a alteração do foco da demanda das informações - do âmbito nacional para o regional e o municipal em função das necessidades ditadas pelo processo de municipalização dos serviços públicos - e a incorporação das estatísticas no processo de implementação, gestão e fiscalização de políticas públicas.

Com a descentralização dos recursos financeiros e a municipalização das políticas sociais, é grande a demanda por informações e indicadores municipais por parte dos órgãos setoriais estaduais para acompanhamento e gestão das políticas públicas municipais. Devido a estas novas atribuições, os municípios e sua realidade local são apontados, atualmente, como as áreas mais carentes de dados sistematizados e organizados, necessários para subsidiar a elaboração de diagnósticos socioeconômicos, o planejamento físico-territorial e a definição das políticas públicas sociais.

A maior participação da sociedade nos processos decisórios e a criação de mecanismos de controle contribuíram para ampliação e diversificação do uso das informações institucionais. Podem ser citados, como exemplo, os conselhos municipais para acompanhamento e avaliação das políticas públicas setoriais, tais como Conselhos Tutelares da Criança e do Adolescente, Conselho Municipal do Idoso, da Condição Feminina, da Comunidade Negra e os Conselhos Municipais de Assistência Social, de Saúde e de Educação. A informação é importante para a participação, permitindo medir e avaliar a realidade. $O$ acesso às bases de informações municipais permite, também, a participação na construção dos indicadores sociais, identificando quais melhor qualificam ou representam a realidade, ou ainda, quais são os mais adequados para avaliação e monitoramento de cada política setorial.

Para atender a tamanha diversidade de usos e amplitude de temas, é necessário que as bases de dados disponibilizadas tenham como suporte sistemas informatizados amigáveis e que sejam organizadas e sistematizadas segundo critérios que facilitem a recuperação da informação.

Entre as informações necessárias para a tomada de decisão municipal, destacam-se os registros administrativos produzidos pelos diferentes setores das 
prefeituras. Observa-se, porém, que eles formam um amplo conjunto de informações dispersas e desarticuladas. Como o objetivo é exclusivamente administrativo, estes dados geralmente não se articulam entre si e tampouco com as informações produzidas nas esferas estadual e federal. Não há, também, preocupação com a manutenção de séries históricas. Para exemplificar esta desarticulação, citam-se as várias regionalizações existentes na administração do Estado de São Paulo. Além da divisão político-administrativa, segundo a qual os 645 municípios estão distribuídos em 42 Regiões de Governo que, por sua vez, compõem 14 Regiões Administrativas e três Regiões Metropolitanas, há mais sete regionalizações com diferentes agregações municipais, estabelecidas por órgãos e secretarias estaduais. Portanto, as informações institucionais produzidas por estes órgãos geram bases de dados com abrangências e agregação diferenciadas, resultando em informações com critérios de coleta e séries históricas não compatíveis, o que dificulta a composição das informações setoriais para formulação de estatísticas e indicadores.

Compatibilização e comparabilidade e organização e sistematização das informações produzidas pelos registros administrativos dos três níveis de governo - municipal, estadual e federal - podem, entretanto, ser extremamente úteis para o planejamento de políticas setoriais, como, por exemplo, para o meio ambiente, disposição final do lixo, qualidade de vida, abastecimento, entre outras.

Uma quantidade infindável de informações é produzida pelos órgãos e institutos públicos de pesquisa, como também inúmeras bases de dados estão disponíveis. O foco das políticas de informação, portanto, deve ser direcionado para o estabelecimento de procedimentos sistemáticos, que possam ser utilizados no processamento das informações para convertê-las em conhecimento útil para usuários específicos, com dados confiáveis e compreensíveis, com possibilidade de acesso em tempo real, sistematizados e disponibilizados em formato compatível com o meio de divulgação. Esses requisitos são essenciais para sua utilização, tanto na tomada de decisão quanto na implementação e fiscalização de políticas públicas. Direcionar a produção e a divulgação das informações para atender às demandas da sociedade depende, por outro lado, da existência de 
políticas de informação que contemplem a implantação de sistemas de organização, recuperação e disseminação dos dados.

Dowbor (2003) enfatiza que o grande desafio que ora se coloca está no ordenamento da informação e nas metodologias de sistematização, através das quais a informação relevante torna-se acessível aos atores que tomam as decisões no momento em que dela precisem:

"a informação bem organizada e disseminada constitui um elemento essencial da democracia participativa, ao facilitar as opções racionais dos diversos atores sociais" Dowbor (2003, p.1).

No caso da divulgação das informações estatísticas na Internet, entre os vários procedimentos de disponibilização,

Lara, Camargo e Rocha (2002, p.89) constatam "a necessidade de oferecer (...) dados mais desagregados (ou seja, variáveis), através dos quais os usuários possam dar forma, eles mesmos, a produtos personalizados desenhados segundo suas necessidades. A proposta seria a de utilizar a Internet como meio de transformar uma disseminação reativa em uma disseminação que permitisse efetivamente contemplar o cidadão como produtor de sentido".

\section{Porém não descartam}

"a divulgação da produção estatística sob a forma de produtos, pois esse é o meio de mostrar o resultado analítico-interpretativo e institucional das pesquisas realizadas" Lara, Camargo e Rocha (2002, p.89).

A disponibilização de informações estatísticas e indicadores não pode ser fragmentada e seletiva, ou dirigida a um determinado setor da sociedade. Ela deve ser feita através um sistema estruturado que facilite as possibilidades de acesso. Os procedimentos de disponibilização devem prever cenários diversificados, acesso às informações mais desagregadas que ampliem as possibilidades de análises e a construção de novas tabulações, além do uso do georreferenciamento das informações e agregações setoriais e/ou regionais, de acordo com os interesses dos usuários. Por outro lado, quando o processo de divulgação é realizado por meio de produtos contendo análises e planos tabulares pré-formatados, os resultados se mostram úteis para auxiliar a interpretação dos 
fenômenos pesquisados e subsidiar o processo de disseminação da base de dados para a sociedade em geral.

É nesse contexto que se insere e se justifica o presente projeto de pesquisa, que procura identificar parâmetros e critérios de organização para formatação de produtos de disseminação de resultados de pesquisas de informações institucionais, com o objetivo de facilitar a recuperação e ampliar o uso das informações. 


\section{2- A METODOLOGIA DE ANÁLISE}

O objeto teórico deste estudo é a organização da informação como meio para sua disponibilização. $\mathrm{O}$ objeto deste de estudo é a base de dados gerada pelas quatro edições da PMU, realizada pela Fundação Seade na década de 1990 (disponibilizada no página www.seade.gov.br), a partir da qual procurarse-á identificar a forma de organização e divulgação de uma base de dados dessa natureza.

Ao definir a base de dados da PMU como objeto de estudo, pretende-se contribuir para a discussão da necessidade de serem adotados princípios de organização para otimizar o uso da informação institucional na gestão das políticas municipais. Partindo do princípio de que a organização da informação é fundamental para prover o acesso e o uso, este o trabalho estará focado na observação dos processos de transformação dos dados coletados através de pesquisas em informação para disseminação. A PMU é um levantamento censitário, cujo universo é o conjunto dos municípios paulistas. A base de dados da PMU é um oportuno objeto de estudo, pois trata-se de pesquisa abrangente e relevante, contendo uma série histórica com periodicidade constante, ou seja, os anos-base 1992, 1995, 1997, 1999 e 2003. Neste sentido, a base de dados da PMU possibilita a investigação quanto à importância da estruturação e organização das informações para dar significado aos dados, tendo em vista o seu uso na geração do conhecimento.

Inicialmente, buscou-se construir o quadro teórico de pesquisa para subsidiar o estudo dos procedimentos de organização e disseminação de informações municipais e institucionais. Serão analisados, no interior da Ciência da Informação, os processos de comunicação em sistemas informacionais, bem como os referenciais na Linguagem Documentária e na Terminologia para organização e tratamento da informação. Também apresentam-se referências para análise do uso do registro administrativo como fonte de informação e dos procedimentos da produção estatística. $\mathrm{Na}$ seqüência, explicitam-se os procedimentos utilizados na PMU para produção de informações, os conceitos correspondentes, as características e as agregações. Nos capítulos seguintes, a partir da análise da PMU, procurar-se-á identificar os problemas de acesso às 
informações disponibilizadas, delimitar novos critérios e propor parâmetros para organização das informações e disseminação da pesquisa.

Assim, o presente projeto pretende:

- introduzir a discussão sobre formas usuais de acesso, considerando a possível existência de barreiras na transmissão da informação que possam interferir na concretização da ação de comunicação, particularmente relacionada aos poderes públicos municipais;

- investigar formas usuais de divulgação de resultados, com base na análise de produtos similares;

- analisar as características do produto tal como é hoje apresentado aos usuários, de modo a investigar como se estabelece a ação da comunicação entre a base de dados e o usuário;

- discutir critérios para tratamento e organização de bases de informações municipais para disponibilização, procedimentos para recuperação da informação e formas de divulgação para atender aos usuários com realidades e necessidades diferenciadas, seja o poder público ou a sociedade em geral. 


\section{3- QUADRO TEÓRICO DE PESQUISA}

No percurso teórico da pesquisa procuramos compreender o que é informação, qual a sua relação com o conhecimento e que diferença tem em relação a ele, focando especialmente as relações na sociedade contemporânea.

\section{1 - Informação e Comunicação}

As informações podem ser definidas, em forma e conteúdo, como

"estruturas simbolicamente significantes, codificadas de forma socialmente decodificável e registradas (para garantir permanência no tempo e portabilidade no espaço) e que apresentam a competência de gerar conhecimento para o indivíduo e para o seu meio. Estas estruturas significantes são estocadas em função de um uso futuro, causando a institucionalização da informação" (Smit e Barreto, 2002, p.21-22).

Segundo os autores, a informação

"não nasce dentro das unidades de informação, nem tampouco tem por finalidade permanecer ad aeternum nessas unidades: sua origem e destino estão fora das unidades de informação, na sociedade que a gera e a transforma em conhecimento" (Smit e Barreto, 2002, p.21-22).

Neste sentido, Baitello (1994) ressalta que o propósito da informação é permitir a produção de conhecimento pelo indivíduo e pelo grupo social em que vive. Por sua vez, a comunicação só se realiza quando uma informação é enviada pela fonte, recebida e compreendida pelo destinatário, possibilitando, portanto, alterações no seu conhecimento. Para que esta condição seja satisfeita, é necessário estabelecer um "código comum" entre a fonte e o destinatário, que atribua regras e significado à transmissão da mensagem. Outra condição essencial é a de que o processo de troca de informação seja recíproco, fluxo de mão dupla dependente do consentimento mútuo do emissor e receptor.

Se o processo de comunicação só se efetiva no plano das relações entre emissão e recepção, o armazenamento torna-se um conjunto de dados organizados ou um estoque de conhecimento em potencial, que precisa ser transmitido, recebido e aceito para se transformar em informação e gerar alterações de conhecimento do receptor. Portanto, decorre do entendimento do 
processo de comunicação a distinção entre os conceitos de conhecimento e informação. O conhecimento é estoque e informação é fluxo, conforme afirma

\begin{abstract}
Barreto (1999): "o repositório de informação representa um estoque potencial de conhecimento, e a sua existência é imprescindível para que se realize a transferência de informação. Contudo, por ser estático, o estoque não produz, por si só, qualquer conhecimento. As informações armazenadas em bases de dados, bibliotecas, arquivos ou museus possuem a capacidade potencial de produzir conhecimento, o que só se efetiva a partir de uma ação de comunicação mutuamente consentida entre a fonte (os estoques) e o receptor".
\end{abstract}

Porém, o processo de comunicação também depende de uma condição contextual e cognitiva, ou seja, para que a informação seja aceita ou assimilada pelo receptor e resulte em alteração de sua consciência, é necessário que este tenha um nível de conhecimento prévio que permita o entendimento da informação e para que possa processá-la, gerando uma nova informação. Para

\begin{abstract}
Barreto (1994, p.3), "a informação é qualificada como um instrumento modificador da consciência do homem e de seu grupo. Deixa de ser uma medida de organização em si; é o conhecimento, que só se realiza se a informação é percebida e aceita como tal e coloca o indivíduo em um estágio melhor de convivência consigo mesmo e dentro do mundo em que sua história individual se desenrola. A informação, quando adequadamente assimilada, produz conhecimento, modifica o estoque mental de informações do indivíduo e traz benefícios ao seu desenvolvimento e ao desenvolvimento da sociedade em que ele vive".
\end{abstract}

A informação, tal como definida neste capítulo, constitui objeto da área de conhecimento da Ciência da Informação, que trata do estudo das propriedades gerais da informação e da análise dos processos de sua construção, de sua comunicação e de seu uso. Para Smit e Barreto, a Ciência da Informação, como campo,

\footnotetext{
"se ocupa e se preocupa com os princípios e práticas da criação, organização e distribuição da informação, bem como com o estudo dos fluxos da informação desde sua criação até a sua utilização, e sua transmissão ao receptor em uma variedade de formas, por meio de uma variedade de canais" (Smit e Barreto 2002, p.17-18).
}

Os autores salientam, porém, que estão em constante processo de revisão o conteúdo e a prioridade dos objetivos da Ciência da Informação, em 
função da "sua interação com uma tecnologia intensa" (Smit e Barreto 2002, p.18).

A Ciência da Informação e a tecnologia da informação abordam os procedimentos de comunicação apoiados em sistemas informatizados relativos à armazenagem e disponibilização da informação. Porém, a Ciência da Informação sofreu forte impacto com as inovações tecnológicas implantadas nas últimas décadas. Segundo Smit e Barreto (2002, p.15), para promover os fluxos da informação, o papel da tecnologia da informação é o de "possibilitar o maior e melhor acesso à informação disponível“. As redes de transmissão são consideradas a infra-estrutura do processo, que facilitam e generalizam o acesso à informação e transmitem com rapidez grandes volumes de informação. Por sua vez, a Ciência da Informação deve intervir

"para qualificar este acesso em termos das competências que o receptor da informação deve ter para assimilar a informação, ou seja, para elaborar a informação para seu uso, seu desenvolvimento pessoal e dos seus espaços de convivência" Smit e Barreto (2002, p.15).

As principais inovações que contribuíram para o atual estágio das tecnologias de informação consistiram na passagem da eletricidade para a eletrônica, do fio de cobre para a fibra ótica, do analógico para o digital e do eletromagnético para o opticoeletrônico. Por outro lado, as técnicas eletrônicas de informação são produtos do conhecimento de três áreas de tecnologias: informática, telecomunicações e mídia eletrônica. Este processo refletiu-se na terceira revolução tecnológica, que se caracterizou pelas alterações dos processos produtivos econômicos e mudanças sociais, que modificaram as formas de trabalho, os meios de produção e as interações organizacionais da sociedade e que deram origem à passagem para o modo de desenvolvimento pós-industrial, ou seja, para a denominada "Sociedade da Informação".

Vários autores referem-se à "Sociedade da Informação", ressaltando a importância, ora da revolução da tecnologia de informação e comunicação, ora da gestão do conhecimento como instrumento indispensável para o processo produtivo e, conseqüentemente, o desenvolvimento econômico. 
Porcaro (2002) ressalta a importância da gestão do conhecimento, ponderando que, na interpretação dos fenômenos que marcam a sociedade atual, a corrente teórica da Sociedade da Informação

"dá maior ênfase ao conhecimento científico e tecnológico, gerador de inovação, como fonte de valor e de crescimento da sociedade. Muitos autores, neste campo teórico, consideram que, apesar da maior visibilidade das informações e das inovações, o central é mesmo o conhecimento, sem o qual não é possível decodificar o conteúdo das informações e transformá-las em conhecimento. O maior destaque dado ao conhecimento deve-se também ao fato de que as inovações tecnológicas resultam de enormes esforços de pesquisa e desenvolvimento, numa geração sistemática de conhecimento" Porcaro (2002).

\section{Já Castells considera que a}

"nova estrutura social está associada ao surgimento de um novo modo de desenvolvimento, o informacionalismo, historicamente moldado pela reestruturação do modo capitalista de produção, no final do século XX" (Castells 2000, p. 32-33).

O autor ressalta, também, que conhecimento e informação são fundamentais em todos os modelos de desenvolvimento, já que a produção baseia-se sempre em algum nível de conhecimento.

"No novo modo informacional de desenvolvimento, a fonte de produtividade acha-se na tecnologia de geração de conhecimentos, de processamento da informação e de comunicação de símbolos" (Castells 2000, p. 35).

"O que é específico ao modo informacional de desenvolvimento é a ação de conhecimentos sobre os próprios conhecimentos como principal fonte de produtividade. O processamento da informação é focalizado na melhoria da tecnologia do processamento da informação como fonte de produtividade, em um círculo virtuoso de interação entre as fontes de conhecimentos tecnológicos e a aplicação da tecnologia para melhorar a geração de conhecimentos e o processamento da informação" (Castells, 2000, p.35).

Estas transformações tecnológicas, além de gerarem impactos nos fluxos de informação, têm efeitos nas relações entre emissão e recepção, ou seja, nos processos de comunicação. Atualmente, com a disponibilização de acervos, textos e bancos de dados em meios eletrônicos e com a implantação de redes, a interação do usuário com os estoques de informações pode ser direta, sem a presença de intermediários. Embora a Internet amplie significativamente a 
abrangência de acesso, é preciso observar que os usuários pertencem a realidades diferenciadas, o que significa dizer que a recuperação da informação não se dá de forma homogênea.

De fato, os processos de disseminação das informações também necessitam de revisão e alteração para torná-los compatíveis com a agilidade da comunicação eletrônica. Barreto (1999) entende que "a comunicação eletrônica, imprime uma velocidade muito maior na possibilidade de acesso, uso e possivelmente de assimilação da informação" e, nesse sentido, pondera que a chegada da sociedade eletrônica de informação também modificou a delimitação de tempo e espaço da informação.

O autor enfatiza a importância das novas relações de interatividade e interconectividade que são estabelecidas entre usuário, estoque e fonte de informação. Por interatividade, Barreto entende a alteração da variável tempo, que

"representa tanto a possibilidade de acesso em tempo real aos diferentes estoques de informação como as múltiplas formas de interação entre o usuário e as estruturas de informação contidas nestes estoques" (BARRETO, 1999).

A relação entre o receptor e a mensagem deixa de ser linear, permitindo a interação com o texto, alterando e/ou introduzindo outros recursos, como imagens, por exemplo. Por outro lado, a conexão em rede modificou a relação do usuário com os espaços da informação, pois permite a interconectividade, ou seja, a possibilidade de transitar de um estoque de informações para outro, como se estivesse colocado virtualmente no interior de um sistema único de armazenamento e recuperação da informação.

Alguns autores consideram que a velocidade com que as inovações tecnológicas são implantadas pode trazer dificuldades para os usuários e afirmam que é equivocada a idéia de que a comunicação eletrônica liberta o texto e a informação da necessidade de intermediação de gestores entre produtores e usuários, pois alguns problemas estruturais dificultam este processo. Conforme sugere Barreto (1998), o instrumental tecnológico é restritivo, em termos econômicos, e seu aprendizado é socialmente pouco difundido. Sem dúvida, a 
velocidade com que a tecnologia evolui tornam obsoletos, cada vez mais rapidamente, os equipamentos e programas aplicativos utilizados, o que gera a necessidade permanente de atualização, envolvendo altos custos tanto para o produtor como para o usuário.

Geralmente, a tecnologia é mais valorizada do que a informação, como acontece com as redes eletrônicas de transmissão, em que o canal é considerado mais importante que a mensagem. Outro problema recorrente refere-se aos produtos eletrônicos disponibilizados, que muitas vezes são tão sofisticados tecnologicamente que chegam a se confundir com o conteúdo, dificultando o acesso e o uso da informação. Por sua vez, nos processos de armazenamento, é necessária a implantação de técnicas alternativas de estocagem e de controle das informações (Barreto, 1994, p.7).

Uma das tendências para o armazenamento de grandes estoques de informação consiste na divisão e especialização dos estoques, no sentido de organizar de maneira adequada o armazenamento e direcionar a distribuição da informação para usuários também especializados. Na opinião de

Barreto (1994, p. 5), "os produtores de informação estão condicionados pelas competências contextuais e cognitivas dos habitantes de realidades diferenciadas; necessitam, pois, adotar estratégias de distribuição, que viabilizem a aceitação de seu produto".

O autor faz distinção entre os produtores de informação, segundo organização, controle e manipulação política e econômica dos estoques. As instituições de pesquisa públicas e privadas, além de criarem a demanda, decidem sobre o conteúdo, detêm a propriedade de estoque de informação, determinam sua distribuição, manipulam a disponibilização e o acesso à informação e condicionam, potencialmente, a produção do conhecimento.

Lara; Camargo e Rocha (2002) concordam com a afirmativa daquele autor de que "a gestão dos estoques de informação pode ser tão autoritária quanto as políticas que a orientam" (Barreto, 2000). Para essas autoras,

"os modelos de organização de informações centrados no emissor corroboram a hipótese de que quem detém o poder sobre a administração e distribuição da informação, também o detém na circulação, decidindo quanto à forma de sua distribuição à sociedade" (Lara; Camargo e Rocha, 2002, p.88). 
Assim, diante da importância da gestão dos estoques de informação, das facilidades proporcionadas pelos canais de comunicação, da abrangência destes estoques e da amplitude do universo de usuários, o uso de procedimentos de organização e de recuperação da informação é condição necessária para promover com eficácia a comunicação. A classificação e o armazenamento das informações devem ser feitos de modo a permitir identificação, seleção e recuperação da informação, tendo em vista demandas diferenciadas. Dessa forma, as instituições, principalmente as públicas, têm a responsabilidade de reavaliar seus processos de comunicação com a sociedade e, para tanto, necessitam rever os procedimentos de pesquisa e as formas de disponibilização de informações para viabilizar a otimização de seu uso.

\section{2 - Organização e Tratamento da Informação}

\subsection{1 - A Linguagem Documentária}

Para que as informações sejam transmitidas ou não desapareçam com o tempo, é necessário dispor de um suporte para registro, viabilizando seu armazenamento, e de um veículo para sua transmissão. Dito de outro modo, os documentos são os suportes da informação, enquanto os livros, revistas e mídias eletrônicas constituem os veículos utilizados para sua disseminação. Uma vez que a transferência da informação, como visto anteriormente, depende da existência de condições de comunicação, é necessário criá-las para que as informações possam circular e resultar em conhecimento. $O$ conjunto de procedimentos para esse fim compreende a conservação, a organização e a elaboração de dispositivos de recuperação.

Para Tálamo, a institucionalização da tarefa de tratar e disseminar a informação tem sua origem nas primeiras bibliotecas, que além da

"tarefa fundamental de preservar o documento escrito, as bibliotecas "facilitavam" o acesso ao conteúdo dos mesmos, submetendo-os a determinadas operações, que sinalizavam a importância de intermediações necessárias para a circulação do conhecimento registrado Tálamo (1997, p.2)." 
Porém, até meados do século passado, os procedimentos limitavam-se às atividades de organização e normalização segundo classes de assuntos, tendo em vista a recuperação bibliográfica.

"Um rápido retrospecto sobre a área mostra que nas décadas de 50 a 60, com o crescimento científico e tecnológico, houve dificuldades para armazenar e recuperar informações. A solução foi encontrada com uma mudança do enfoque e da conceituação da recuperação da informação. Vem dessa época a utilização de Linguagens Documentárias - LDs para a recuperação da informação. Essas linguagens são, pois, construídas para indexação, armazenamento e recuperação da informação e correspondem a sistemas de símbolos, destinadas a "traduzir" os conteúdos dos documentos" (Cintra et al., 1994, p. 23).

No contexto da Análise Documentária, as LDs são instrumentos intermediários, ou de comutação, através dos quais se realiza a tradução da síntese dos textos e das perguntas dos usuários. Por sua vez, a Análise Documentária constitui uma metodologia desenvolvida no interior da área de Documentação, que se dedica ao estudo de metodologias para análise, síntese e representação da informação, visando a sua recuperação.

A metodologia para representação documentária prevê a geração de, pelo menos, dois produtos: uma síntese em forma de resumo elaborada com base na análise do documento; e um índice obtido a partir de um processo de tradução por meio de identificação de termos que compõem a linguagem especialmente construída para a área objeto de estudo.

A linguagem utilizada no processo de tradução é denominada Linguagem Documentária, sugerindo-se mais recentemente que seja vista como uma Linguagem de Organização da Informação, para não restringir seu uso às formas convencionais dos produtos documentários (Lara, 1999). Essa ampliação permite contemplar gêneros de informações, como as administrativas e as estatísticas, ressaltando-se que sua forma deve obedecer às características específicas.

"A Linguagem Documentária - normalmente composta por um conjunto limitado de termos denominados "descritores" - prescreve as formas de entrada e de busca a serem utilizadas pelo indexador ou pelo usuário, num sistema documentário. Por ser assim construído, tal instrumento integra elementos resultantes de escolhas feitas em um universo lexical amplo. Suas unidades têm origem tanto em Linguagens de Especialidade, como na 
linguagem de uso corrente e nas Terminologias de área" (Cintra et al. 1996, p.18).

Neste sentido, as LDs requerem um conhecimento prévio do usuário sobre o assunto pesquisado, pois são consideradas metaliguagens, ou seja, são linguagens construídas com o objetivo de estabelecer referências ou intermediação entre as informações (conteúdo do texto) e os usuários.

Este conjunto completo de termos de indexação utilizados em um sistema de recuperação recebe, às vezes, a denominação de vocabulário ou linguagem de indexação, sendo este vocabulário controlado por um conjunto de relações à maneira lógico-semântica. Nestes sistemas, os termos formam uma estrutura construída com base nos conceitos da área de estudo, em que as relações estabelecidas entre os conceitos (dos termos ou descritores) são de natureza hierárquica, associativa e de equivalência.

Entre os vários tipos de LDs, o instrumento de representação e organização da informação considerado mais moderno e desenvolvido é o tesauro, que prevê o controle terminológico e a estrutura organizacional baseada na relação lógica-semântica. O tesauro é definido como um vocabulário controlado de uma linguagem de indexação, formalmente organizado para explicitar as relações entre conceitos. Para obter o controle de vocabulário, são recomendados procedimentos quanto à seleção dos termos, que devem ser restritos a um único significado considerado mais pertinente. Tal controle gera a opção por um termo preferido, mesmo quando o conceito puder ser expresso por dois ou mais sinônimos.

Segundo as "Diretrizes para o estabelecimento e desenvolvimento de Tesauros Monolíngues" (Austin \& Dale, 1993), as orientações mais importantes referem-se às relações básicas que unem os termos de um tesauro, as quais não são apenas entre termos, mas também entre categorias e subcategorias. A norma trata da definição de três classes de relações recíprocas, que são expressas em um sistema de símbolos ou abreviaturas: 
- relação de equivalência - ocorre entre o termo preferido e o não-preferido, em que dois ou mais termos são considerados, para fins de indexação, referentes ao mesmo conceito. A relação de equivalência compreende:

- os sinônimos - são termos cujos significados podem ser considerados semelhantes em um grande número de contextos, sendo, portanto, virtualmente intercambiáveis;

- os quase-sinônimos - são termos cujos significados são geralmente considerados diferentes no uso comum, mas são tratados como se fossem sinônimos para fins de indexação;

- o envio de um termo específico para um genérico - os nomes de uma classe, e de seus membros são considerados um conjunto equivalente; o termo genérico desta forma funciona como o termo preferido;

- relação hierárquica - esta relação básica faz distinção, principalmente, entre um tesauro sistemático e uma lista não estruturada, um glossário ou um dicionário. Baseia-se em graus ou níveis de superordenação ou subordinação, em que o termo subordinado refere-se a seus membros ou partes. A reciprocidade é expressa pelas abreviaturas TG (termo genérico) e TE (termo específico). São tipos de relação hierárquica:

- relação genérica - identifica o vínculo entre a classe ou categoria e seus membros ou espécies. Esta relação pode ser objeto do teste lógico todos e alguns;

- relação hierárquica todo-parte - os termos podem ser organizados como uma hierarquia, em que o nome do todo funciona como termo superordenado e o nome da parte como subordinado;

- relação de exemplo - identifica a ligação entre uma categoria geral de objetos ou eventos, expressa por um substantivo comum, e um exemplo individual daquela categoria;

- relações polihierárquicas - alguns conceitos podem pertencer, em bases lógicas, a mais de uma categoria ao mesmo tempo; 
- relação associativa - ocorre entre pares de termos que não são membros de um conjunto de equivalência e nem podem ser organizados em uma hierarquia na qual um termo subordina-se a outro, mas que se interrelacionam quanto ao sentido, num determinado contexto. Esta é uma relação recíproca e representada pela abreviatura TR.

Como já mencionado, a metodologia para construção de LDs foi desenvolvida com o objetivo de criar um instrumento para armazenamento e recuperação da informação, através da representação do conteúdo do documento, entendendo-se por documento os mais diversos tipos de suporte para registro do conhecimento. Neste sentido, esta metodologia pode ser aplicada na organização de informações para disponibilização de bases de dados institucionais e estatísticos, ou seja, no processo que envolve o armazenamento e a recuperação da informação com o objetivo principal de transmiti-la para que possa resultar em conhecimento.

Outra propriedade das LDs que condiz com as características dos processos de divulgação das informações estatísticas é a possibilidade de atualizações e adaptações. Conforme salientam

Cintra e colaboradores (1994, p.34), "uma vez elaboradas e postas em uso, as LDs mais desenvolvidas, como os tesauros, são permanentemente atualizadas, mediante operações de supressão de termos em desuso, reagrupamento de descritores em função da existência de palavras raramente utilizadas e/ou adição de termos novos. Só assim as LDs se mantêm como instrumentos dinâmicos, capazes de incorporar os avanços do conhecimento, ou as modificações de significado de termos já existentes".

As bases de dados estatísticos também são dinâmicas e, geralmente, abrangem séries históricas que incorporam novos conceitos ou novos procedimentos de produção da informação. Por sua vez, os usuários pertencem a realidades diferenciadas, são heterogêneos e as demandas são diversificadas, exigindo, assim, que tanto a linguagem como o formato do produto disponibilizado atendam a este universo. 
A importância das metodologias de construção de LDs para a organização da informação relaciona-se à operacionalização de redes estruturais de relacionamento. Tendo em vista que não existe informação fora de contexto, a rede relacional proposta permite localizar os termos a partir de oposições recíprocas. Esse procedimento tem sua origem na observação da língua, na qual as palavras só têm significado quando opostas umas ás outras, seja por escolha entre classes de palavras substituíveis pelo seu valor, seja por contraste (combinação) (Lopes, 1987).

\subsection{2 - A Terminologia}

A Ciência da Informação é uma área de trabalho que se constitui a partir do empréstimo e do esforço para apropriação de conceitos de outras áreas, como, por exemplo, da Lógica, da Lingüística e, mais recentemente, da Terminologia.

A Terminologia1, do ponto de vista da Ciência da Informação, é o instrumento que referenda o processo de organização da informação, sua transferência e circulação, ao identificar e modelar o sistema de conceitos de áreas de conhecimentos da ciência para possibilitar a comunicação entre os especialistas.

Segundo Sarger (1993), a Terminologia é uma disciplina que pode ser definida como "o sistema das linguagens técnicas e das formas disponíveis para expressar os conceitos complexos das ciências e das tecnologias que nos afetam diretamente", sendo que os dicionários, os tesauros e os bancos de dados terminológicos são ferramentas que facilitam e resolvem os problemas de comunicação mono e multilingue entre os especialistas, o público e os profissionais intermediários nos processos de comunicação.

No final do século $X X$, tornou-se crescente a importância da Terminologia para os processos de comunicação, principalmente com o grande

\footnotetext{
${ }^{1}$ A palavra Terminologia, neste estudo, é utilizada com $\mathrm{T}$ maiúsculo quando se refere à disciplina teórica metodológica e com t minúsculo quando trata-se de terminologia concreta (dicionários, glossários e outros produtos terminológicos).
} 
desenvolvimento das ciências e das inovações tecnológicas (Sarger, 1993). À medida que o conhecimento é ampliado, ocorre uma especialização da língua a partir daquela utilizada para a comunicação no cotidiano: os níveis de conhecimento das áreas são diferenciados, assim como os de linguagem são distintos dentro de uma mesma área, como ocorre, por exemplo, com o discurso didático, o de divulgação e o técnico, entre outros. Ainda de acordo com

Sarger (1993), "a divisão entre línguas gerais e linguagens específicas, com suas terminologias respectivas, se encontra na base da estrutura que nossa sociedade tem dado ao conhecimento e às profissões que o representam".

Conseqüentemente, o domínio que cada pessoa tem do seu idioma é parcial e determinado por vários fatores: cultura, educação, profissão e procedência.

Sem dúvida, existem níveis diversos de saber. O especialista não conhece toda a matéria da sua área de conhecimento, assim como não domina toda a língua especializada; por outro lado, o profissional da informação domina a linguagem especializada, mas não a matéria. Do ponto de vista da Ciência da Informação - como também da área de Terminologia -, o profissional da informação deve conhecer a linguagem especializada com o objetivo de operar "traduções" - pontes de mediação - não com o intuito de adquirir competência do mérito do conhecimento da matéria, mas sim para que a informação possa ser organizada com o objetivo de promover sua circulação.

A Terminologia pode ser definida como a disciplina que se dedica ao estudo dos conceitos e dos termos usados nas línguas especializadas, com o propósito de identificar as relações e estabelecer sistemas de conceitos. De acordo com

Cintra e colaboradores (1996, p.20), o objetivo da Terminologia é "organizar e harmonizar as noções ou conjunto de noções dos domínios específicos do conhecimento. Através de procedimentos sistemáticos a Terminologia seleciona e/ou cria termos para as noções, relacionando-os através de definições. Obtém-se, desse modo, repertórios ou listas de termos especializados de um domínio particular, acompanhados de definições que remetem o termo ao seu referente. Tais listas apresentam-se como classificações científicas conceituais, podendo ser agrupadas segundo uma classificação alfabética ou temática". 
Dito de outro modo, a principal função da Terminologia

"é a de observar as unidades da língua natural e da comunicação especializada e propor a representação de conceitos e sistemas de conceitos através de termos". Portanto, ela "assume funções de comunicação e de representação, procura o consenso e propõe formas de controle da diversidade de significação" (Lara, 2002, p.5).

Ainda segundo Lara, a Terminologia se propõe a objetivos diferenciados:

"a Terminologia teórica visa mostrar que ela é parte do conhecimento e da atuação dos especialistas e dos mediadores, propondo-se a verificar como é usada a terminologia em diferentes níveis de atuação - comunicação profissional entre especialistas, ensino de especialidades, divulgação científica etc. A terminologia prática se expressa nos trabalhos de tradução, documentação, normalização lingüística, planejamento lingüístico; concretamente, serve à construção de dicionários, glossários, tesauros, etc" (Lara 2002, p.5).

A unidade básica da terminologia é o termo. Os termos são unidades cognitivas relacionadas a sistemas de conceitos que representam o conhecimento de uma área de domínio; são unidades de expressão e comunicação que visam transferir o conhecimento especializado da área representada. Portanto, os termos são palavras usadas nos discursos de especialidade e diferem daquelas que, por sua vez, pertencem ao léxico geral.

O uso da Terminologia substituiu o processo empírico de construção das LDs - ou seja, a seleção de termos que inicialmente era realizada através da avaliação de sua freqüência e ocorrência na literatura -, por um processo sedimentado em princípios teóricos-metodológicos consistentes (Lara, 1999). A estruturação ou arranjo dos descritores de uma LD baseia-se em um dos sistemas de conceitos. Por sua vez, o significado dos descritores corresponde ao dos termos de uma língua de especialidade, que são encontrados na terminologia concreta (vocabulários, glossários e dicionários técnicos). A estruturação dos termos é necessária para garantir que cada termo remeta a um único significado dentro da língua de especialidade. Dito de outra forma, 
"é preciso buscar referências de estruturação (...) de significado para os termos, ou seja, verificar como a língua de especialidade do domínio transforma a palavra, a partir de seu uso concreto no discurso da especialidade, em unidade de significação precisa. Não basta, entretanto, recolher um a um os termos do domínio. Para que a linguagem documentária ganhe uma significação própria como um todo e nas suas unidades, é preciso que ela tenha um arranjo próprio, construído a partir do relacionamento mútuo entre os termos" (Lara, 2002, p.8).

Em conjunto com as Terminologias, a linguagem de especialidade e a linguagem natural utilizada pelos usuários devem constituir o universo referencial para a construção das LDs. Neste sentido, as linguagens documentárias são definidas por

Cintra e colaboradores (1996, p.21) como "classificações intermediárias, já que responderiam pela sistematização de ao menos três paradigmas designacionais: a linguagem de especialidade (núcleo de idéias), as classificações científicas e suas definições (terminologias de áreas) e a linguagem natural".

A importância social adquirida pelo conhecimento e formação especializados nos últimos tempos, é um dos motivos da tendência da construção de LDs altamente especializadas. Neste sentido, o emprego da Terminologia como instrumento de operação na construção das LDs é importante para assegurar o processo de comunicação. Segundo

Tálamo (2001, p.148) "são nas fronteiras entre a Terminologia e a Lingüística Documentária que se podem identificar as diferenças entre termos e descritores, e a contextualização dos espaços de trânsito da informação, a partir dos quais desenham-se as políticas de informação".

\section{3 - Informação Administrativa como Fonte para Informação Estatística}

Atualmente, para as agências estaduais, uma das opções viáveis para construção de sistemas de informações voltados para subsidiar e monitorar as políticas públicas corresponde ao levantamento de dados e informações através de pesquisa secundária. O fator custo, como já foi mencionado, é a principal vantagem da coleta de informações nos órgãos e instituições públicas quando comparada a pesquisas primárias, que demandam recursos financeiros muito elevados. 
"são submetidas a freqüentes constrangimentos financeiros, em razão da crise de financiamento por que vem passando o Estado brasileiro nos últimos anos, os registros administrativos devem ser encarados como uma alternativa para a produção de estatísticas, principalmente no que se refere às relativas aos municípios (Guizzardi, 2004, p.5).

Além disso, a variável tempo também é fundamental: as demandas exigem respostas precisas e em tempo hábil e os registros e cadastros públicos estão informatizados, o que permite maior facilidade e agilidade na coleta das informações.

A grande desvantagem da fonte secundária é que os registros constituem anotações da administração pública e de outras instituições referentes às suas atividades, com o objetivo de acompanhar, avaliar e prestar contas para as autoridades competentes (Guizzardi, 2004). Assim, como as instituições são distintas e os procedimentos para anotação da informação são diferenciados, não há preocupação com a estabilidade e a comparabilidade das informações. Tais problemas são relacionados por

Guizzardi (2004, p.5): para que essa produção possa se dar com estabilidade e consistência, são necessárias, no entanto, medidas que garantam o acesso aos registros administrativos bem como a participação direta das agências produtoras de estatística em sua concepção, na implantação dos mecanismos para seu levantamento junto aos informantes e no controle de seus resultados".

Com medidas desse gênero, o uso das informações administrativas podem ser potencializadas.

\subsection{1 - A produção da informação estatística}

\subsubsection{1 - Agentes - institutos de pesquisas socioeconômicas}

A missão dos institutos de pesquisas socioeconômicas é possibilitar a múltiplos usuários o conhecimento sobre a realidade da sociedade, através da produção e disseminação de pesquisas, análises e estatísticas socioeconômicas e demográficas. 
O Instituto Brasileiro de Geografia e Estatística - IBGE, órgão coordenador do Sistema Estatístico Nacional ${ }^{2}$, subordinado ao Ministério do Planejamento, Orçamento e Gestão, oferece uma visão completa e atual do país, através do desempenho de uma de suas principais funções: a produção e análise de informações estatísticas e geográficas. Outra função do IBGE, igualmente importante, consiste na coordenação e consolidação do desenvolvimento de metodologias para produção das informações estatísticas junto às agências estaduais. Este instituto é o principal provedor de dados e informações do país, realizando, além do Censo Demográfico, com periodicidade decenal, o Censo Agropecuário, pesquisas amostrais anuais, como a PNAD (Pesquisa Nacional por Amostra de Domicílios), pesquisas econômicas (Pesquisa Anual do Comércio, Pesquisa Industrial Anual, Pesquisa Anual da Indústria da Construção e Pesquisa Anual de Serviços) e a Pesquisa Mensal de Emprego. Estes são os levantamentos considerados estruturantes, que cobrem boa parte dos interesses e necessidades de informação, atendendo aos mais diversos segmentos da sociedade civil, bem como aos órgãos das esferas governamentais federal, estadual e municipal.

Por sua vez, as agências estaduais de pesquisas concentram-se na produção de informações descentralizadas e mais focadas nas necessidades e preocupações específicas das esferas estadual e municipal. A demanda por informações em nível mais agregado é atendida, em parte, pelas pesquisas estruturantes do IBGE, mas aquela referente a informações temáticas ou mais desagregadas não é suprida. Cabe às agências estaduais preencher esta lacuna, geralmente através do desenvolvimento de metodologias de pesquisas secundárias realizadas nos órgãos estatais.

Para Januzzi e Gracioso (2002, p.97), apesar da insuficiência de recursos financeiros e humanos das agências estaduais, há "um esforço crescente de algumas instituições em coletar dados através de pesquisas diretas de campo, em domicílios ou estabelecimentos", principalmente sobre emprego e rendimento. Outras iniciativas nessa direção são o desenvolvimento de

\footnotetext{
${ }^{2}$ Sistema Estatístico Nacional é composto pelo IBGE e pelas agências estaduais
} 
indicadores de monitoramento de políticas sociais semelhantes ao IDH - Índice de Desenvolvimento Humano e a disponibilização de

"dados de interesse ao planejamento público como os indicadores de finanças públicas, estatísticas de emprego formal, habitação e serviços urbanos, segurança pública e previdência, compiladas a partir de registros administrativos de órgãos públicos em diferentes níveis" (Januzzi e Gracioso, 2002, p.97).

Também são notórios o empenho e a preocupação das instituições estaduais no sentido de realizar levantamentos de dados para suprir a demanda por informações relacionadas a temas ainda não devidamente cobertos, e que atualmente são considerados prioritários na definição das políticas públicas, como por exemplo, segurança pública, recursos naturais e abastecimento.

Em relação ao âmbito municipal, o IBGE, abrangendo todos os municípios do país, e a Fundação Seade, para os municípios paulistas, disponibilizam bases de dados municipais e indicadores relativos a diferentes áreas da administração municipal, tais como: programas sociais em saúde, educação e habitação; oferta de serviços de infra-estrutura urbana (transporte, coleta de lixo e saneamento básico); finanças públicas municipais; instrumentos de gestão pública; etc. As fontes destas informações são os registros administrativos e os cadastros municipais, cujos dados são coletados através de pesquisa junto às prefeituras.

No âmbito nacional, no que se refere à produção de estatísticas públicas e às políticas e procedimentos de produção e disponibilização das informações estatísticas pelas agências estaduais, Gracioso pondera que o Sistema Estatístico Nacional

"está consolidado e é o principal responsável pelas informações estatísticas brasileiras, podendo ser-lhe agregadas características de confiabilidade, credibilidade e perenidade no desenvolvimento de pesquisas e análise de dados, obtendo assim lugar de destaque em relação a demais órgãos estatísticos de países da América Latina, por exemplo" (Gracioso, 2003, p.73). 


\subsubsection{2 - Fontes de coleta de informações}

Além daquelas resultantes das principais pesquisas do IBGE, as informações socioeconômicas disponibilizadas pelas agências estatais, também são coletadas através de pesquisas primárias ou de levantamentos em fontes secundárias. As pesquisas primárias são aquelas em que a coleta dos dados é realizada diretamente nos domicílios ou estabelecimentos e geralmente são amostrais. São pesquisas que demandam recursos humanos capacitados, o custo é muito elevado e o processo, desde o desenvolvimento da metodologia até a disponibilização das informações, é muito longo. Portanto, de modo geral, as bases de dados destas instituições são compostas por informações coletadas em fontes secundárias, ou seja, nos registros e cadastros públicos dos órgãos estaduais e municipais das administrações direta e indireta e dos Cartórios de Registro Civil.

A utilização dos registros administrativos e cadastros técnicos, como fontes de dados para gestão e planejamento, depende das suas características qualitativas e da eficiência como instrumentos de controle. O uso de dados de diferentes sistemas de informação também requer atenção especial por parte dos técnicos, pois podem ocorrer problemas de estabilidade e comparabilidade dos dados.

Alguns Ministérios (Fazenda, Saúde, Educação e Justiça) e Secretarias de Estado, por meio de seus cadastros ou registros administrativos, também disponibilizam bases de dados e/ou informações estatísticas através da Internet ou de publicações periódicas, como os anuários.

A seguir, apresentam-se exemplos de fontes secundárias de informação, segundo o tipo de registro.

- Os Cartórios de Registro Civil, com seus registros públicos, constituem as principais fontes de dados para os institutos de pesquisa, viabilizando a produção de informações demográficas, bem como a elaboração de estudos e análises sobre a dinâmica populacional e de projeções demográficas, em âmbito municipal. Também a partir dos registros civis são calculadas as estatísticas vitais: taxa de mortalidade por causa de morte, sexo e idade; 
fecundidade; natalidade; e nupcialidade. No Brasil, o fato de o registro civil ser uma atribuição do Poder Judiciário, delegada a Cartórios de Registro Civil, dificulta a obtenção de estatísticas vitais,

"a cobrança de taxas e as distâncias geográficas dos cartórios são barreiras efetivas para a legalização de atos civis para parcela significante da população brasileira, de baixa renda e/ou residentes nos pequenos municípios do interior" (Jannuzzi, 2001, p.52).

- Instituições da administrações públicas, como exemplo, pode-se citar a Secretaria Estadual de Educação, órgão que exerce e fiscaliza a atividade do ensino. Os registros administrativos disponibilizados por esta Secretaria (número de escolas, de matrículas e de conclusões, de salas de aula, de professores, etc.) são produzidos pelas instituições de ensino público muitas das quais pertencem à própria Secretaria - e privados.

"Instituições como administrações públicas, cartórios, empresas, hospitais, escolas e sindicatos produzem quantidades imensas de anotações necessárias ao acompanhamento e à avaliação de suas atividades ou à prestação de contas para as autoridades fiscais, normativas ou regulatórias: essas anotações constituem-se os chamados registros administrativos" (Guizzardi, 2004, p.8).

- Outras fontes de informação são os cadastros produzidos pelos órgãos públicos referentes às atividades produtivas, como, por exemplo, a RAIS (Relação Anual de Informações Sociais) e o CAGED (Cadastro Geral de Empregados e Desempregados), disponibilizados pelo Ministério do Trabalho, que possibilitam análises quanto à estrutura ocupacional dos mercados de trabalho regionais, programas de qualificação de mão-de-obra, taxa de rotatividade da mão-de-obra, entre outros indicadores.

- Os órgãos estaduais e municipais (da administração direta, empresas públicas ou concessionárias), responsáveis pelos serviços públicos de infraestrutura (uso e ocupação do solo urbano, abastecimento de água, limpeza pública, luz, vias públicas, rodovias, etc.), geralmente possuem cadastros técnicos atualizados das redes dos serviços prestados e informações sobre os usuários. Em alguns casos estes cadastros são, inclusive, georreferenciados constituindo-se numa importante fonte de dados. 
Dependendo do processamento e da periodicidade das atualizações, estes cadastros, podem servir como fonte de informações para formulação e avaliação de projetos urbanos e políticas relacionadas aos serviços públicos.

\subsubsection{3 - Metodologia de produção de informação}

O procedimento de geração de bancos de informações socioeconômicas e das estatísticas produzidas pelos institutos de pesquisas socioeconômicas, para efeito de análise do processo, pode ser dividido em de três etapas: formulação, quando são definidos os conteúdos e a metodologia; coleta que se refere ao levantamento de campo; e disponibilização das 3informações. Segundo Senra (2000), para cada uma destas etapas, podem ser relacionados atributos da informação que devem ser considerados durante o processo de produção.

Etapa de Formulação

- Pertinência - refere-se à relevância, intimamente ligada à questão do propósito e objetivo dos usuários. Requer a inclusão de temas emergentes e pressupõe 0 atendimento das demandas de analistas políticos e de responsáveis pela elaboração das políticas.

- Utilidade - relevância situacional ou utilitária, refere-se à utilidade para a tomada de decisão e à adequação da informação para resolução de problemas e redução de incertezas. As informações estatísticas devem ser comparáveis e combináveis.

- Abrangência - o dimensionamento da a mostra deve prever a inclusão de grupos que podem ser demograficamente importantes, mas não suficientemente relevantes em termos numéricos para serem estatisticamente significativos.

Etapa de Coleta

- Validade - base de dados que garanta a qualidade da procedência dos dados: adequação técnica, baseada num arcabouço conceitual (consistência teórica); precisão quanto ao processo de pesquisa e confiabilidade das 
fontes dos dados; adequação do dado quando a origem da informação é produzida para outros propósitos.

- Possibilidade de obtenção em tempo hábil - disponibilizada no momento em que é necessária.

Etapa da Disponibilização

- Continuidade - sistematização, permanência ao longo do tempo e estabilidade da classificação.

- $\quad$ Visibilidade - deve ser acessível e compreendida (aceita) pelo usuário.

- Integridade - ligada à credibilidade, precisão e confiabilidade dos dados.

Considerando o crescente processo de expansão da comunicação eletrônica, é essencial atentar para aspectos relativos à divulgação dos resultados de pesquisas socioeconômicas, bem como de estatísticas e indicadores:

- $\quad$ procedimentos de disponibilização;

- $\quad$ formas de recuperação das informações;

- $\quad$ fator obsolescência - maior velocidade na circulação da informação;

- $\quad$ delimitação de tempo e espaço da informação;

- relações dos usuários com as estruturas de informação:

- interatividade - acesso em tempo real e a múltiplas formas de interação entre os usuários e as estruturas de informação;

- interconectividade - permite ao usuário da informação deslocarse, no momento em que desejar fazê-lo, de um para outro espaço de informação.

A revisão sistemática do processo de formulação das pesquisas socioeconômicas e dos indicadores estatísticos é essencial, pois as mudanças sociais são contínuas e cada vez mais aceleradas. Em relação aos indicadores oficiais, estes correm o risco de não serem pertinentes para propiciar conhecimento sobre os diferentes contextos da sociedade, uma vez que recentemente, não só os produtos foram substituídos, mas também foram 
alterados os processos produtivos, os meios de prestação de serviços e as relações de trabalho. Conseqüentemente, também foram alteradas as funções das unidades de análise das pesquisas estatísticas: o domicílio, a empresa, o posto de trabalho, etc. (Porcaro, 2001).

Em relação à gestão das políticas públicas, também ocorram mudanças. O processo de municipalização das políticas sociais, em direção à descentralização político-administrativa, altera as formas de gestão e amplia a oferta de serviços públicos. Neste sentido, a produção de informações municipais assume papel cada vez mais estratégico enquanto instrumento de gerenciamento dos sistemas municipais e para subsidiar o diálogo entre o poder central, os gestores estaduais, a prefeitura municipal e a sociedade civil.

\subsubsection{4 - Produtos de informações socioeconômicas}

As agências estaduais e o IBGE têm disponibilizado diversos produtos impressos e em meio digital, além dos tradicionais Anuários Estatísticos. Geralmente, estes produtos compõem um sistema de estatísticas e indicadores com recorte temático e/ou regional, agregam informações de diversas fontes e têm por objetivo a disseminação de informações para a sociedade.

Jannuzzi (2001) define conjunto de Estatísticas Públicas como o

"conjunto de dados sociais, demográficos e econômicos coletados, copilados e disponibilizados regularmente pelas agências ligadas ao Planejamento Governamental e outras instituições públicas para a sociedade civil, governo e empresas. Corresponde aos dados provenientes de Censos Demográficos, pesquisas amostrais e registros administrativos, produzidos pelo IBGE, órgãos estaduais de estatística, Ministérios, Secretarias de Estado e Prefeituras" (Jannuzzi, 2001, p.133).

Quanto ao suporte para divulgação de sistemas de informações estatísticas, cabe ressaltar que as publicações impressas ainda são consideradas importantes para o processo de disseminação, mas os conteúdos, em geral, se restringem a textos analíticos, tabelas, gráficos e mapas, principalmente devido a limitações de custo e tempo de produção. A partir da última década, os produtos ganharam um novo suporte físico: o meio digital, que possibilita a 
disponibilização, no mesmo produto, de várias formas de apresentação das informações: textos analíticos, tabelas, gráficos, mapas, ou mesmo a base de dados completa, a partir da qual o usuário pode criar outras agregações ou novos conjuntos analíticos, de acordo com seu interesse.

É consenso, entre os autores, que o advento da tecnologia do CD-ROM e da Internet trouxe enormes benefícios para as agências de estatísticas em relação às políticas e aos procedimentos de divulgação das informações. Se comparados com as publicações impressas, como os Anuários Estatísticos, as vantagens dos sistemas de informações em meio digital são inúmeras: baixo custo de produção; agilidade na disponibilização da informação; grande capacidade e suporte para armazenamento de bases de dados, e, principalmente, possibilidade de atendimento às necessidades do usuário, permitindo que ele organize ou estruture as informações com recortes temáticos, espaciais ou temporais, conforme o cenário que deseja investigar (Jannuzzi e Gracioso, 2002, p.100).

Entretanto, como mencionado anteriormente, os sistemas informacionais interativos e complexos também podem trazer dificuldades para o usuário, pois o instrumental tecnológico é restritivo, em termos econômicos, e seu aprendizado é socialmente pouco difundido, nem sempre atingindo, portanto, o objetivo de disseminação da informação.

Do ponto de vista da Ciência da Informação, para alcançar os resultados pretendidos, ou seja, gerar conhecimento, é necessário ponderar sobre como se efetivam os processos de comunicação e de transmissão das informações. É importante que na estrutura do sistema de disponibilização sejam considerados critérios de tratamento e organização da informação, com base nas metodologias de construção de linguagens de organização da informação e da terminologia, bem como nos contextos de circulação da informação, ou seja, os usuários.

Neste sentido, segundo LARA e CONTI (2003, p.32) "o grande problema da disseminação é a criação de condições para facilitar o fluxo de informações para propiciar o conhecimento. E ele reside na linguagem, ou mais especificamente, nas linguagens, que requer, antes de tudo, a existência de elos de significação entre produção e recepção. Não se pode confundir, 
porém, os meios com as mensagens. (...) também não se deve esquecer que os meios são distintos e devem ser utilizados considerando suas especificidades. Do mesmo modo, cada meio (ou suporte informacional) é caracterizado por linguagem própria. Assim como para cada tipo de usuário há uma linguagem e uma informação, cada meio é mais (ou menos) apropriado para diferentes tipos de informação".

Outro aspecto abordado por alguns autores e considerado bastante relevante para a socialização das estatísticas é a divulgação da metodologia de produção, incluindo: identificação das fontes; metodologia de pesquisa; instrumento de pesquisa; arcabouço conceitual; glossários de termos; princípios de equivalência e de padronização, na forma de classificações e ordenamentos; etc. (Senra, 2002, p.81). Produtos analíticos, tabulações e bases de dados desagregadas, divulgados através de publicação impressa ou meio eletrônico, quando acompanhados de informações sobre a metodologia de produção, permitem o conhecimento das limitações, das abrangências e do correto entendimento das estatísticas, ampliando, assim, as possibilidades do uso da informação pela população.

Ainda em relação às políticas de disseminação das informações estatísticas, é importante salientar que, atualmente, verifica-se que a demanda tem recebido atenção especial das instituições estaduais de pesquisas, permitindo definir os requisitos para uma política de divulgação.

"O diagnóstico de que grande parte dos usuários tem dificuldades não só de acesso, mas principalmente de compreensão destas informações, pode ser considerado grande avanço por parte das agências estaduais" (Graciosos 2003, p.74).

No presente projeto de pesquisa, interessa especificamente o estudo da estrutura e organização destes produtos como meio para facilitar o acesso às informações.

\subsection{2 - O usuário das informações socioeconômicas}

Até pouco tempo, as informações socioeconômicas e estatísticas públicas eram utilizadas apenas por órgãos estatais incumbidos do planejamento 
das políticas públicas, pelo setor privado da atividade econômica onde estavam centralizados os processos de tomada de decisão e pela universidade para elaboração de estudos acadêmicos. Hoje, esta visão está em processo de mudança; entidades da sociedade civil organizada são incorporadas ao conjunto de

\begin{abstract}
"potenciais usuários da informação de suporte aos processos decisórios". A informação estatística "deixou de figurar apenas nos diagnósticos e relatórios governamentais, ganhando um papel mais relevante nas arenas de discussão político-social da sociedade brasileira, na avaliação dos avanços ou retrocessos nas condições de vida da população, no apontamento de eficácia das políticas públicas ou na defesa técnica quanto às prioridades sociais a atender" (Jannuzzi e Gracioso, 2002, p.93).
\end{abstract}

Da mesma maneira, e com as novas formas de gestão dos serviços públicos (concessão, terceirização ou agência reguladora), a informação também é considerada fundamental nos procedimentos de regulação destes serviços, como salienta

Low-Beer (2000, p.8): "a informação desempenha um papel de destaque na regulação dos serviços públicos, constituindo-se em ferramenta para o controle e monitoramento dos padrões da prestação de serviços, estando subjacente à definição das formas e dos objetos das relações entre produtores (independentemente de sua natureza pública, privada ou mista) e consumidores, às distintas condições de operação dos diferentes sistemas, e à articulação inter-setorial".

No contexto da tomada de decisão, os órgãos públicos, os planejadores econômicos, as instituições de pesquisa, as organizações não-governamentais e o setor privado compõem a lista dos principais usuários de informação, segundo a Comissão de Desenvolvimento Sustentável (CDS) das Nações Unidas (Mousinho, 2001, p.10). Porém, a autora destaca também a importância da mídia e da população, bem como o papel desejável destes usuários nos processos decisórios:

- mídia - manter determinados temas em foco ou fazer chegar ao público as informações; 
- população - cobrança e acompanhamento das questões públicas, assim como das posições assumidas e decisões tomadas pelos agentes responsáveis.

Atualmente, com a crise fiscal do Estado e a implantação de novos programas sociais para combater o agravamento das desigualdades sociais, sistemas de informações setoriais são importantes para a identificação dos públicos-alvo dos programas sociais propostos e para monitorar a implementação das políticas públicas.

Alguns autores salientam que o universo de informações produzidas pelos institutos de pesquisas e órgãos públicos já é extremamente amplo, mas é necessário que a informação seja organizada e estruturada dentro de um sistema integrado que viabilize o uso desta informação para o processo de tomada de decisão tanto do setor público, da sociedade civil organizada como do próprio cidadão.

Para Lara; Camargo e Rocha (2002) a motivação do cidadão

"usuário de informações estatísticas relaciona-se à satisfação de uma necessidade também utilitária, mas, em geral, não individual: sindicatos, associações de classe, organizações não governamentais e empresas procuram informações estatísticas para poder fazer frente às necessidades coletivas, sejam elas relativas à de seus direitos, seja para o planejamento de sua atuação na sociedade. Apenas uma pequena parcela dos usuários procura informação estatística para reflexão, como é o caso de pesquisadores acadêmicos" (Lara; Camargo e Rocha, 2002, p.87).

Outro aspecto importante refere-se à abrangência de um sistema de informações, para a CDS:

"a tomada de decisão é um processo cíclico, que em geral envolve cinco etapas, havendo necessidade de informação disponível para cada uma delas" (MOUSINHO, 2001, p.9):

- identificação do problema;

- formulação de políticas;

- implementação;

- monitoramento do desempenho e

- avaliação. 
Sem dúvida, cada uma destas etapas exige um conjunto de informações específicas. A identificação do problema envolve, principalmente, abrangência, quantificação e qualificação. Quanto à formulação de políticas e implementação, além do orçamento, é necessário dimensionar, qualificar e quantificar os beneficiários e simular cenários. O entendimento de que a estatística também é parte do processo de fiscalização é recente. Existe a preocupação, por parte de especialista, com o desenvolvimento de metodologias para a construção de indicadores de monitoramento e avaliação de políticas sociais.

Para análise ou monitoramento de políticas públicas específicas, seja na fase de implementação, seja na de acompanhamento, são utilizados conjuntos de indicadores que possibilitam a construção de sistemas de indicadores setoriais. Geralmente, estes sistemas referem-se a uma temática social específica, como o Sistema de Indicadores sobre a Saúde, o Sistema de Indicadores Ambientais, o Sistema de Indicadores para acompanhamento do Mercado de Trabalho, etc.

\subsection{3 - A relação produção / usuário: oferta e demanda}

Barreto (1994, p.7) afirma que "no âmbito das trocas de informação é a oferta que cria a demanda por informação". Esta afirmação é entendida como válida no âmbito da Ciência da Informação, considerando os processos de comunicação e transferência de conhecimento. No entanto, pode-se observar que a oferta, mais do que determinar, condiciona a demanda, sendo necessário atentar para os casos de demanda reprimida. No âmbito das informações socioeconômicas e estatísticas públicas, usualmente a produção dos órgãos e institutos de pesquisas públicos também é baseada na oferta, mas este procedimento é questionado, pois alguns autores entendem que, neste caso, a demanda tem papel importante e deva ser atendida.

Por sua vez, Dowbor (2003) afirma que os órgãos e institutos de pesquisa públicos produzem informações

"segundo uma filosofia da oferta, daquilo que a instituição considera que deveria produzir, com pouca consideração da demanda, ou seja, daquilo que a sociedade precisa saber para uma participação política informada" (DOWBOR, 2003, p.6). 
Já, Senra (2000) argumenta que a demanda por informações estatísticas produzidas pelos institutos de pesquisas socioeconômicas tem duas expressões temporais:

- durante a produção, na etapa de formulação, as informações demandadas têm dimensão sociopolítica, denominando-se de demanda anterior, que é estrutural e estruturante, pois é ela que motiva a oferta. Estas estatísticas que comporão o sistema de informações devem cobrir um extenso leque de temas relevantes e abrangentes, capazes de permitir a exaustiva compreensão de uma certa realidade;

- na etapa de disseminação, as informações demandadas têm dimensão técnico-científica, denominando-se demanda posterior. Apenas para esta dimensão é válida a tese de que a oferta é que determina a demanda. Para o autor, a dimensão técnico-científica significa tornar as informações acessíveis e compreensíveis para os usuários e representar de maneira precisa a realidade.

Para este autor, os agentes que compõem a demanda anterior, vinculada à etapa de formulação, estão situados nos vértices do "triângulo da demanda" formado por governo, mercado (atividades econômicas) e comunidade (sociedade civil organizada).

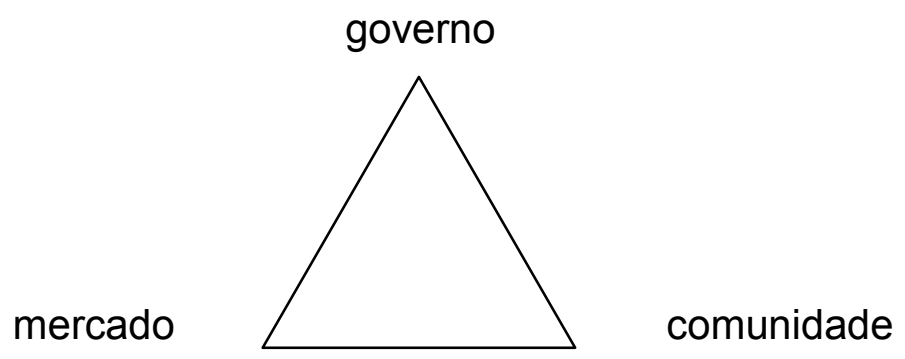

Embora o governo seja o principal agente e o de maior peso, uma vez que determina e produz o maior volume de demandas, não deve ser o único foco, pois o mercado e a comunidade também necessitam de informações diversificadas relativas a todas etapas do processo de tomada de decisão. 
As pesquisas socioeconômicas mais abrangentes e estruturantes, base para o sistema de indicadores sociais e informações estatísticas, são produzidas por órgãos estatais e, portanto, as demandas do governo são identificadas com maior facilidade, geralmente resultantes de um processo contínuo e estruturado ao longo do tempo. O mesmo não é válido para as informações demandas pelo mercado e pela sociedade civil, o que torna necessário que os institutos ampliem o foco de suas políticas para identificar e atender às necessidades destes usuários. Devido à importância na definição da estrutura de informações que serão disponibilizadas, as demandas destes três agentes devem ser objeto de estudo e análise constantes.

Complementarmente, Senra (2000) salienta que três questões devem orientar o processo de detecção da demanda para cada um dos agentes:

- $\quad$ identificação dos agentes em cada vértice do triângulo;

- $\quad$ identificação dos desejos e necessidades desses agentes;

- identificação das reais possibilidades e limitações em atender com qualidade e presteza aos desejos e necessidades devidamente relacionados.

Na opinião de

Lara; Camargo e Rocha (2002, p.87-88), "entre os elementos que constam na origem do problema (de acessibilidade) destaca-se o uso de um modelo de mensuração da realidade fortemente centrado no emissor, o que, por si só, já representa uma restrição porque desconsidera o usuário. (...) O enfrentamento da demanda padece da ausência de metodologias aptas a identificar seu perfil e é realizado ou supondo um usuário potencial, imaginado, ou com base em uma análise reativa, valendo-se de suas dúvidas e solicitações como parâmetro para sua definição".

Entretanto Jannuzzi e Gracioso (2002) ponderam que os institutos de pesquisa vêm alterando a sistemática de disponibilização das informações, deixando de ser menos reativos ao atender a posteriori as necessidades do usuário, para tornarem-se mais pró-ativos, preocupando-se com a identificação das demandas nas etapas de formulação e disseminação. 


\section{4 - A PESQUISA MUNICIPAL UNIFICADA - PMU}

\section{1 - O Contexto da Pesquisa}

Na década de 80, o processo de concentração urbana sofreu expansão, ultrapassando os limites da Região Metropolitana de São Paulo. Surgiram novas áreas de crescimento urbano, devido ao desenvolvimento econômico e à capacidade de absorção de contingente populacional. Com a consolidação de centros regionais no interior do Estado, os municípios que compõem a Região Metropolitana de São Paulo passaram a apresentar taxas de crescimento inferiores às de cidades do interior.

Esse processo de expansão do desenvolvimento econômico decorre de investimentos diretos realizados pelo poder público em infra-estrutura, modernização da agricultura e expansão da agroindústria, do desenvolvimento industrial direcionado para o entorno da Região Metropolitana e dos problemas relacionados às deseconomias de aglomeração na Região Metropolitana de São Paulo, que contribuíram para a dispersão da população no interior. Municípios localizados no entorno de centros regionais, que apresentavam taxas negativas de crescimento, já na década de 80 manifestavam recuperação demográfica. Esta dinâmica da rede urbana no Estado de São Paulo, nos anos 80 e 90, levou ao crescimento de cidades médias, onde houve concentração de população e a articulação com regiões metropolitanas.

A Constituição Federal de 1988 contribuiu para a alteração dos papéis dos três níveis do poder Executivo: a União perdeu recursos financeiros para os Estados e Municípios que, por sua vez, assumiram as políticas sociais antes promovidas pela União. Também a dinâmica da globalização intensifica e modifica as forças sociais, acentuando a nova atribuição dos municípios: o de promover o desenvolvimento econômico, relacionando-se com o setor privado e objetivando o desenvolvimento social.

O papel dos municípios também foi alterado em função dos novos parâmetros políticos e da ampliação das exigências da sociedade. Entretanto, foi nos anos 90 que se consolidaram os processos de desconcentração da 
população e dispersão da migração no interior, a expansão do desenvolvimento econômico e as mudanças institucionais pós-Constituição de 1988.

Estes redirecionamentos ampliaram as demandas, dirigidas às instituições de pesquisas estatais, por informações sociais, econômicas e demográficas mais desagregadas, em função da necessidade de os municípios formularem suas políticas públicas e da institucionalização do processo de planejamento público em âmbito local (Jannuzzi, 2001).

Se, por um lado, as exigências da sociedade foram ampliadas, por outro, a resposta dada pelo poder local também foi alterada de acordo com seu papel neste novo cenário e sua capacidade de gestão e implementação de novas políticas públicas.

Ainda na esfera local, a sociedade civil, principalmente a organizada, diante da sua crescente participação na gestão municipal, também passou a usar e demandar informações e indicadores sociais e urbanos às instituições de estatísticas.

Neste sentido, a Fundação Seade que tem como missão estatutária a coleta, o tratamento, a análise e a disseminação de informações socioeconômicas sobre a realidade paulista, desenvolveu metodologia de pesquisa - Pesquisa Municipal Unificada - para coletar dados e informações nas prefeituras, com o objetivo de obter resposta a algumas indagações.

- Como o poder local se estrutura para o enfrentamento das novas questões relativas às políticas administrativas, sociais e urbanas?

- Quais são os instrumentos legais existentes para promover o controle ou incentivo do desenvolvimento urbano e econômico?

- Como os municípios incorporaram novas formas de gestão e se recapacitaram financeiramente, transformando e incrementando receitas próprias para assumir políticas sociais antes pertencentes a níveis superiores de governo?

- Como os vários municípios - de pequeno, médio e grande portes pertencentes a uma dada rede urbana regional se articulam entre si e com 
outras regiões para definição e implementação políticas setoriais e na área social?

Segundo a Fundação Seade, ao focar nas prefeituras sua fonte primária de dados, a PMU procura aquilatar o desempenho das gestões municipais diante dos atribuições que os municípios vêm assumindo na administração das políticas públicas, principalmente aquelas de cunho social. A PMU visa, também, disponibilizar informações sobre a realidade socioeconômica dos municípios paulistas para atender à demanda dos administradores públicos, empresários, cidadãos e pesquisadores de informações, conforme especificado a seguir.

- Secretarias e Órgãos de Estado - subsídios para definição de políticas públicas regionais e setoriais.

- Prefeituras municipais - sistema de informações estruturado com dados do município e dos demais que responderam a pesquisa, servindo como referencial para o município.

- Universidades e institutos de pesquisa - informações para realização de estudos e pesquisas sobre administração municipal.

- Empresas privadas e público em geral - informações para estudos de mercado, decisões de investimentos e acompanhamento da implementação de políticas públicas.

A seguir, é apresentada mais detalhadamente a estratégia aplicada nas diferentes fases da pesquisa, cujas atividades podem ser agrupadas em três etapas: pré-campo, que corresponde ao processo de planejamento da pesquisa; operação de campo, abrangendo a etapa de coleta e consistência dos dados; e pós-campo, que compreende a disponibilização das informações.

\section{2- A Etapa de Planejamento da Pesquisa}

A Pesquisa Municipal Unificada coleta dados e informações sobre a evolução da estrutura organizacional e administrativa, dos recursos humanos e financeiros das prefeituras municipais, bem como procura captar elementos referentes à implementação e gestão de políticas públicas globais e/ou setoriais e 
dos serviços públicos. Em 1999, a pesquisa abrangeu os seguintes temas e conteúdos: Estrutura Administrativa; Comunicações e Informatização, Estrutura Urbana; Habitação; Saneamento Básico; Limpeza Pública; Transporte Municipal; Saúde; Assistência e Desenvolvimento Social; Educação; Cultura, Esportes e Turismo; Abastecimento; e Finanças Municipais.

Para a realização da PMU, a Fundação Seade estabelece convênios com órgãos estatais interessados nas bases de dados. Estas instituições, copatrocinadoras da pesquisa, participam na etapa de elaboração dos questionários, que procuram abarcar questões que respondam às demandas das mesmas.

Apesar de já consagrados como instrumentos de pesquisa, os questionários passam por um processo de revisão e aprimoramento a cada nova edição. As equipes técnicas da Fundação Seade trabalham no aperfeiçoamento do questionários, adaptando-os às alterações dos rumos das políticas setoriais, como da saúde e da educação, por exemplo, e discutindo seus conteúdos com técnicos envolvidos na gestão e no acompanhamento destas políticas. Essas reformulações, no entanto, levam em consideração a importância da manutenção da série histórica do núcleo principal da pesquisa.

O instrumento utilizado é o questionário para autopreenchimento do respondente. As questões, organizadas em blocos/seções, levantam dados de natureza quantitativa e qualitativa (variáveis categóricas). ${ }^{3}$

O questionário é padrão para todos os municípios e foi definido no sentido de captar a estrutura organizacional das prefeituras. Dessa forma, a resposta negativa, ou a não existência do fenômeno, ou, ainda, a não disponibilidade dos dados são tão importantes quanto a resposta afirmativa e quantificada.

A pesquisa é censitária, pois seu universo é o conjunto de todos os municípios do Estado de São Paulo e a unidade de investigação básica da PMU é

\footnotetext{
3 "Variáveis categóricas: apresentam uma qualidade (ou atributo) da unidade pesquisada. Com elas não podem ser feitos cálculos matemáticos, como soma e médias, mas apenas contagem de respostas por categorias" (Fundação Seade).
} 
a prefeitura municipal, compreendendo todos os seus órgãos de administração direta, bem como todas as entidades da administração indireta.

\section{3 - A Etapa de Coleta dos Dados}

Tendo em vista o tamanho do universo pesquisado e a amplitude dos temas e variáveis levantadas, a PMU utiliza estratégias que visam garantir a mais ampla cobertura, fidedignidade e qualidade dos dados, de forma ágil e em prazos relativamente curtos.

Essas estratégias consistem, basicamente, em:

- $\quad$ envolver a prefeitura no processo de coleta de dados, através da indicação de um coordenador municipal;

- $\quad$ organizar o material da pesquisa de forma a facilitar sua distribuição entre os diferentes órgãos administrativos, agilizando, assim, a coleta de dados;

- enviar os questionários pelo correio, via sedex, e monitorar o recebimento e preenchimento;

- $\quad$ recolher e realizar a crítica e consistência em campo.

Desta forma, a estratégia adotada garante que os questionários cheguem a todos os municípios, sejam distribuídos e recolhidos por um agente da própria prefeitura. A organização da pesquisa em diferentes cadernos visa agilizar a coleta de dados, uma vez que procura seguir a organização administrativa da maior parte das prefeituras paulistas, propiciando a distribuição dos questionários pelo coordenador.

Já, a estrutura operacional do campo é definida e montada tendo em vista um trabalho que não se resume apenas à coleta dos dados, incluindo também, como atribuição dos pesquisadores, a conferência e a revisão das informações, obedecendo a critérios estabelecidos através de parâmetros de crítica. Esta estratégia permite um ganho de qualidade na confiabilidade dos dados e no tempo despendido entre a realização da pesquisa e a disponibilidade dos mesmos. 
As informações coletadas são digitadas em um programa de entrada de dados que prevê a verificação de conteúdo válido para cada variável dos questionários, com o armazenamento dos dados em gerenciador de banco de dados. Para atender à metodologia da pesquisa, o programa é estruturado em três módulos: de entrada de dados; de consistência; e de controle. Na entrada de dados, a estrutura do questionário é reproduzida na tela o que permite maior agilidade na digitação. Neste módulo também é realizada a consistência quanto ao fluxo do questionário. A consistência dos dados é mais um recurso do sistema que certifica e assegura a qualidade das informações coletadas e que permite a emissão de relatórios de eventuais inconsistências. O módulo de controle da pesquisa registra as ocorrências decorrentes da investigação do pesquisador, segundo a metodologia aplicada, e permite que os coordenadores e supervisores, através de recursos de geração de relatórios, realizem o acompanhamento e monitoramento da pesquisa.

\section{4 - A Etapa de Disponibilização das Informações}

Nesta etapa, as informações são objeto de uma nova crítica informatizada e, posteriormente, são validadas pela equipe de analistas da instituição. A crítica eletrônica consiste na comparação dos dados coletados com os parâmetros estabelecidos, considerando a evolução temporal dos fenômenos pesquisados quanto à existência e à quantificação, quando for o caso. Para os valores numéricos são estabelecidos intervalos de aceitação do dado. Cada questionário temático é reavaliado pela equipe setorial, que através da análise e com base nos parâmetros estabelecidos, valida a informação e, quando necessário, retorna ao campo para esclarecimento de dúvidas com o informante na prefeitura ou recuperação de dados. Os dados que ainda apresentarem pendências ou inconsistências não são disponobilizados.

A Fundação Seade disponibiliza a base de dados contendo a série histórica das quatro edições da PMU, em produto eletrônico e na Internet na página da instituição. O produto permite a recuperação de todas as variáveis para o conjunto dos municípios pesquisados. 


\title{
5 - PESQUISAS MUNICIPAIS - DISPONIBILIZAÇÃO E RECUPERAÇÃO DOS RESULTADOS
}

No Brasil, geralmente, os produtos disponibilizados pelos órgãos estaduais de estatística, tanto em meio digital como na Internet ou na versão impressa, restringem-se às edições de anuários estatísticos dos Estados e perfis municipais. As informações divulgadas são de fontes diversas: registros administrativos de órgãos estaduais e federais e banco de dados do IBGE.

\begin{abstract}
"Um dos aspectos importantes que caracteriza a produção das agências estaduais é a natureza secundária dos dados estatísticos manipulados. De modo geral, as agências têm a incumbência de buscar informações produzidas nas diversas secretarias estaduais e compilá-las em um anuário ou compêndio de dados. É certamente uma função importante, necessária e mesmo estruturante das agências estaduais, que justifica sua existência e pode garantir sua perenidade institucional" (Jannuzzi e Gracioso 2002, p.97).
\end{abstract}

Pesquisas primárias junto às prefeituras municipais, com periodicidade regular, com o objetivo de estruturar uma base com dados desagregados por municípios, são realizadas apenas pela Fundação Seade - a PMU - e pelo IBGE (Pesquisa de Informações Básicas Municipais - MUNIC). Ainda segundo Jannuzzi e Gracioso (2002) é a insuficiência de recursos financeiros e humanos que dificulta a produção primária de dados por parte dos órgãos estaduais.

"Certamente as pesquisas do IBGE - como as PNADs (Pesquisa Nacional por Amostra de Domicílios) e Pesquisas Econômicas - cobrem boa parte dos interesses e necessidades de informação em nível agregado (estadual ou metropolitano, em alguns casos), mas evidentemente não responde a questionamentos mais específicos temáticos e em termos de desagregação espacial requeridos pelos usuários dos sistemas estaduais de planejamento" (Jannuzzi e Gracioso, 2002, p.97).

\section{1 - O Caso da PMU}

O produto digital Pesquisa Municipal Unificada, anos-base 1992, 1995, 1997 e 1999 é disponibilizado pela Fundação Seade no site www.seade.gov.br e em CD-ROM para instalação local. A base de dados obtida pela pesquisa é disponibilizada através de sistema desenvolvido em ambiente Windows, com interface amigável, de fácil navegação e utilização pelo usuário, permitindo a 
realização de consultas por temas de interesse e seleção de áreas geográficas e variáveis de interesse.

Para iniciar a pesquisa, o usuário deve selecionar um dos treze temas disponibilizados e, em seguida, um assunto (subtema) pertinente (Figura 2). Após a seleção das variáveis (Figura 3 ), deve-se escolher a abrangência geográfica. $O$ usuário pode optar por selecionar os municípios de uma ou mais regiões administrativas ou regiões de governos ou ainda selecionar diretamente os municípios através de lista organizada por ordem alfabética (Figura 4). As informações referentes ás variáveis selecionadas são visualizadas e recuperadas, por município, para as quatro edições da pesquisa em formato de planilhas (Figura 5), que podem ser impressas ou armazenadas em meio digital.

A estrutura da base de dados utilizada no produto para a recuperação da informação é a mesma construída para realizar a digitação de dados na etapa de campo. Entretanto, que a estrutura e a organização da base resultante da entrada de dados têm objetivos específicos e não são apropriadas para a disponibilização e recuperação dos resultados da pesquisa, pois obrigam o usuário a selecionar todas variáveis que constam na questão para obter um único dao, além de produzir informações desnecessárias, conforme ilustram as Figuras 3 e 5.

A Figura 1 é a reprodução da tela do questionário de Saneamento Básico da PMU-99, referente à questão que procura identificar a natureza jurídica da empresa operadora do sistema de saneamento básico do município. A questão é estruturada de maneira a atender aos objetivos da pesquisa, ou seja, captar a estrutura organizacional das prefeituras, procurando, portanto, abranger todas as alternativas de resposta e considerando também que o instrumento de coleta é padrão para todos os municípios e para autopreenchimento do respondente.

A estrutura da base de dados resultante da etapa de coleta é definida de acordo com: a metodologia da pesquisa, que prevê que todos campos referentes a cada variável devem ser preenchidos pelo respondente; os 
procedimentos de entrada de dados no sistema informatizado; e os processos de crítica e consistências dos dados coletados.

Considerando-se, que os objetivos do acesso são diferentes dos de coleta, entende-se que a base de dados disponibilizada deve ser estruturada segundo parâmetros diferentes para facilitar o acesso à informação. 
FIGURA 1 - Tela do questionário de Saneamento Básico - Bloco sobre Administração - PMU 99

\section{1- ADMINISTRAÇÃO}

1.1.1- Indique, no quadro a seguir, a natureza jurídica da empresa operadora do Sistema de Saneamento Básico no Município, em 1999.

\begin{tabular}{lcc}
\hline \multicolumn{1}{c}{ Natureza Jurídica } & $\begin{array}{c}\text { Abastecimento } \\
\text { de Água } \\
\text { 1 SIM 2 NÃO }\end{array}$ & $\begin{array}{c}\text { Esgoto } \\
\text { Sanitário } \\
\text { 1 SIM 2 NÃO }\end{array}$ \\
\hline Administração Direta da Prefeitura & $\left.1001\right|_{-} \mid$ & $\left.1002\right|_{-} \mid$ \\
Empresa ou Autarquia Municipal & $\left.1003\right|_{-} \mid$ & $\left.1004\right|_{-} \mid$ \\
Empresa Privada & $\left.1005\right|_{-} \mid$ & $\left.1006\right|_{-} \mid$ \\
Empresa Pública Estadual (Sabesp) & $\left.1007\right|_{-} \mid$ & $\left.1008\right|_{-} \mid$
\end{tabular}

1.1.2- Caso tenha assinalado, na questão anterior, "Empresa ou Autarquia Municipal" e/ou "Empresa Privada", indique sua(s) denominação(ões).

Empresa ou Autarquia Municipal

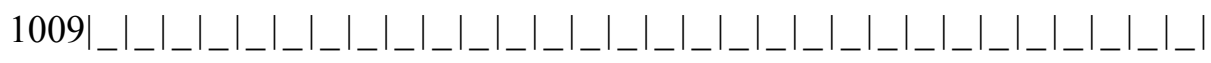

Empresa Privada

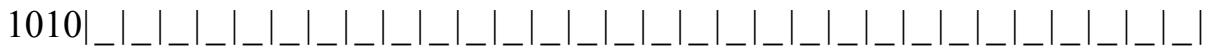


FIGURA 2 - Tela do produto Pesquisa Municipal Unificada disponibilizado no site www.seade.gov.br Seleção do tema Saneamento Básico e do assunto Administração

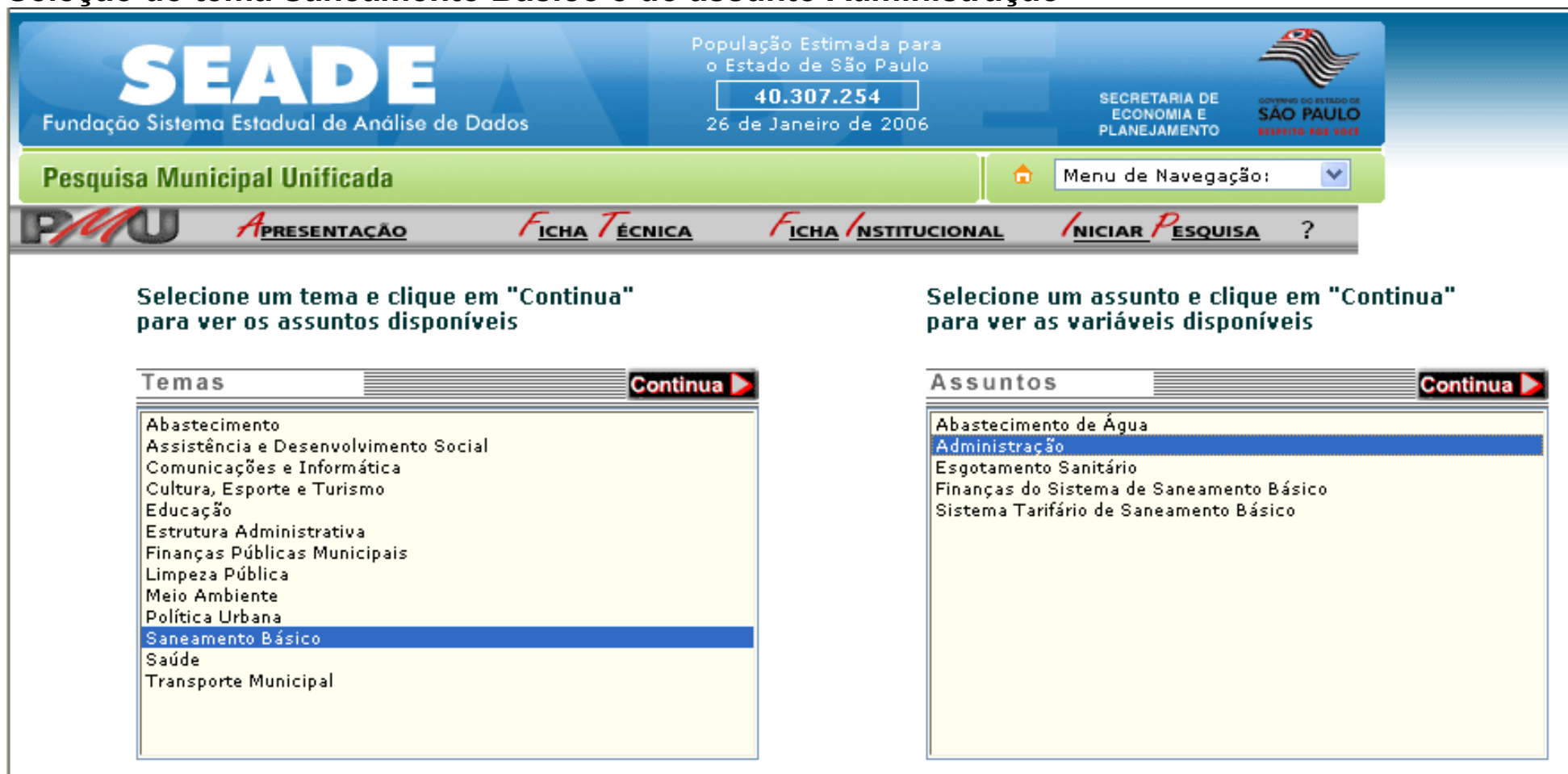


FIGURA 3 - Tela do produto Pesquisa Municipal Unificada disponibilizado no site www.seade.gov.br Seleção das variáveis relativas à natureza jurídica das empresas operadoras dos sistemas de abastecimento de água e esgoto sanitário.

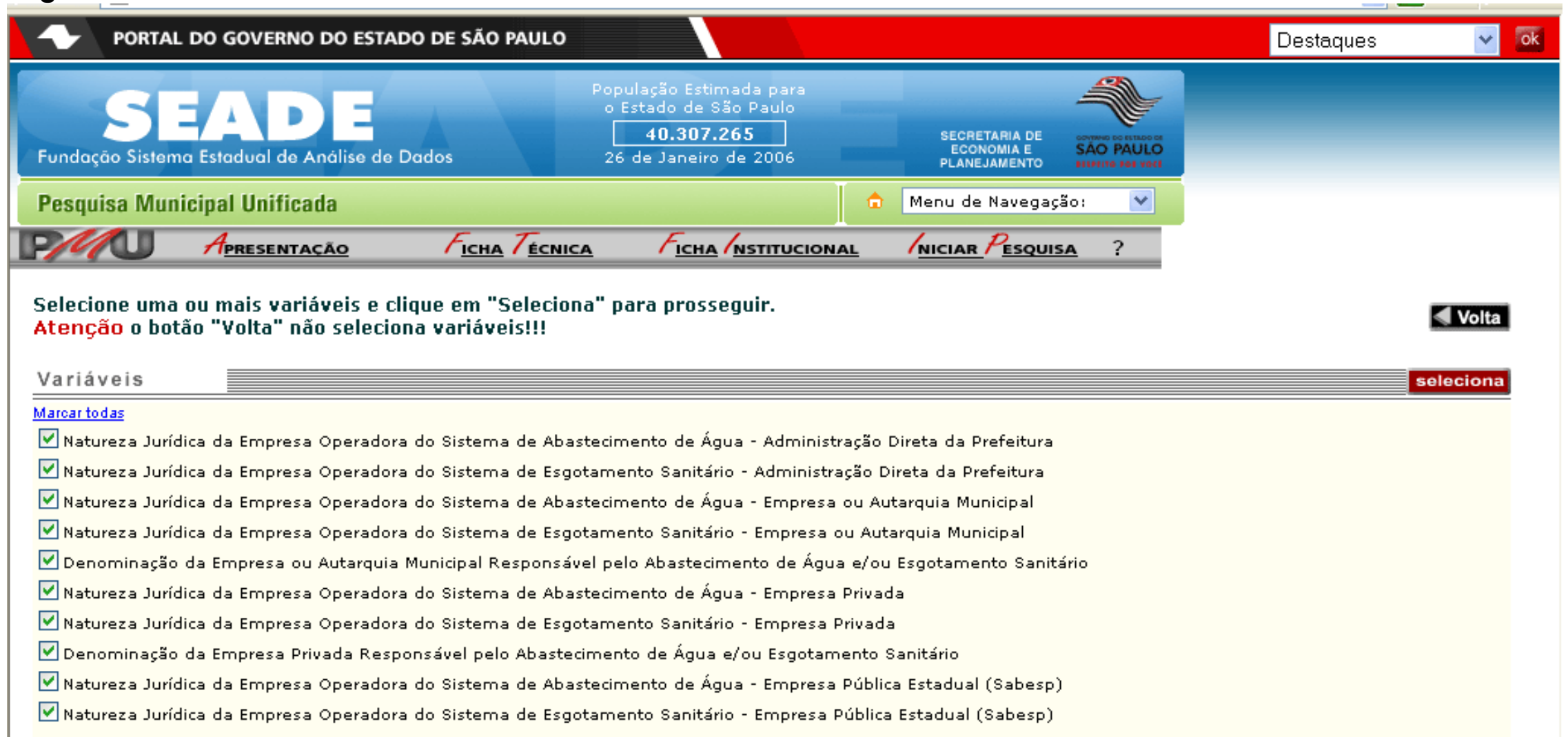


FIGURA 4 - Tela do produto Pesquisa Municipal Unificada disponibilizado no site www.seade.gov.br Seleção da abrangência geográfica - município.

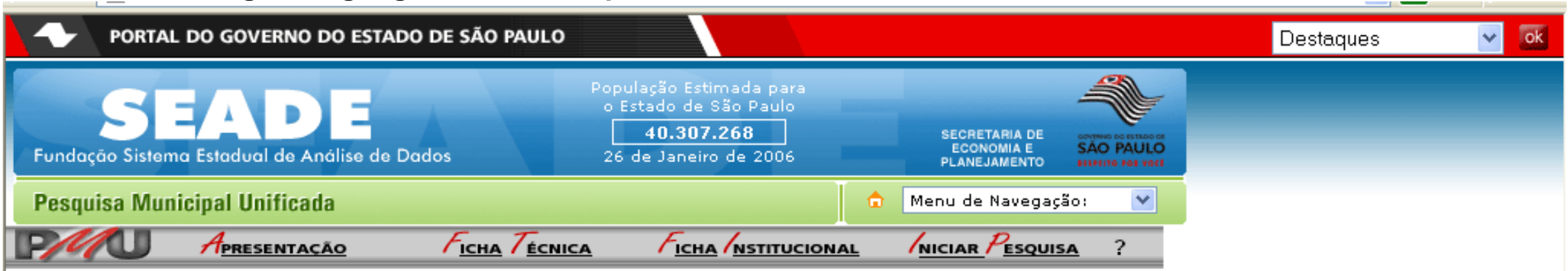

\section{Tema}

Selecione uma ou mais regiẫo e clique em

"Continua" para ver os municípios da região.

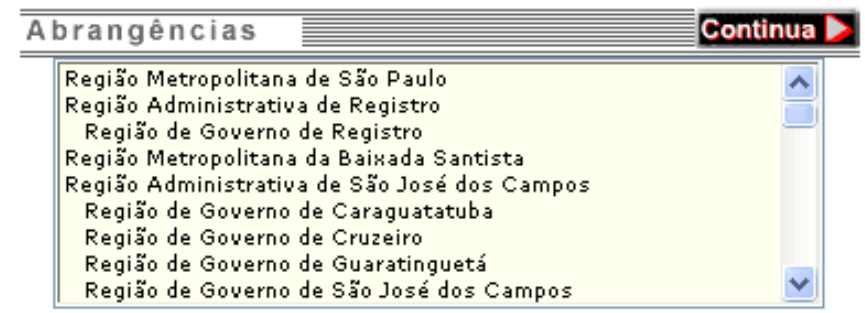

Digite abaixo o nome do município ou as suas primeiras letras e clique em "Continua".

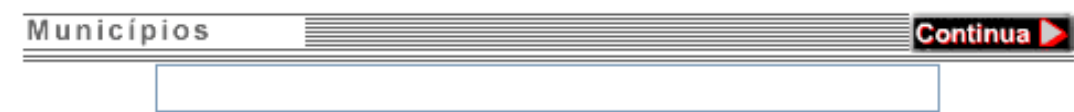

Selecione um ou mais Municípios e clique em "Continua" para ver Resultado.

\begin{tabular}{|c|c|}
\hline Municipios & Continua D \\
\hline Cajati & $\hat{A}$ \\
\hline Cajobi & \\
\hline Cajuru & 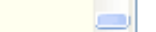 \\
\hline Campina do Monte Alegre & \\
\hline Camoinas & \\
\hline Campo Limpo Paulista & \\
\hline $\begin{array}{l}\text { Campos do Jordão } \\
\text { Cananéia }\end{array}$ & $\underline{v}$ \\
\hline
\end{tabular}




\section{FIGURA 5 - Resultado da busca de informações sobre a Natureza Jurídica da Empresa Operadora do Sistema de Saneamento Básico do Município de Campinas.}

Município: Campinas

\section{Variáveis \\ Saneamento Básico} 1992

1995

1997

1999

Natureza Jurídica da Empresa Operadora do Sistema de Abastecimento de Água Administração Direta da Prefeitura

DNP DNP DNP Não

Natureza Jurídica da Empresa Operadora do Sistema de Esgotamento Sanitário Administração Direta da Prefeitura DNP DNP DNP Não

Natureza Jurídica da Empresa Operadora do Sistema de Abastecimento de Água Empresa ou Autarquia Municipal

DNP DNP DNP Não

Natureza Jurídica da Empresa Operadora do Sistema de Esgotamento Sanitário Empresa ou Autarquia Municipal

Denominação da Empresa ou Autarquia

Municipal Responsável pelo

Abastecimento de Água e/ou

Esgotamento Sanitário

Natureza Jurídica da Empresa Operadora do Sistema de Abastecimento de Água Empresa Privada

Natureza Jurídica da Empresa Operadora do Sistema de Esgotamento Sanitário Empresa Privada

Denominação da Empresa Privada

Responsável pelo Abastecimento de Água e/ou Esgotamento Sanitário

Natureza Jurídica da Empresa Operadora do Sistema de Abastecimento de Água Empresa Pública Estadual (Sabesp)

Natureza Jurídica da Empresa Operadora do Sistema de Esgotamento Sanitário Empresa Pública Estadual (Sabesp)

DNP DNP DNP Sim

DNP DNP DNP Sim

DNP DNP DNP

Sociedade de

DNP DNP DNP Abastecimento de Água

e Saneamento S/A

DNP DNP DNP Não

DNP DNP DNP Não

Fonte: Fundação Sistema Estadual de Analise de Dados - SEADE Pesquisa Municipal Unificada - www.seade.gov.br
(...) Dados não disponíveis
( - ) Fenômeno inexistente
(DNP) Dado não pesquisado
(NR) O município não respondeu à pesquisa
(MI) Município inexistente à época da realização da pesquisa 


\section{2 - O Caso da MUNIC}

O IBGE tem realizado, a partir de 1999, a Pesquisa de Informações Básicas Municipais - MUNIC aplicada no universo dos municípios brasileiros. Os objetivos e as metodologias da PMU e MUNIC são muito semelhantes, principalmente no que se refere ao instrumento de coleta e aos procedimentos de campo.

Da mesma maneira que a PMU para os municípios paulistas, a MUNIC tem por objetivos:

"constituir uma base de informações institucionais em nível municipal;
propiciar a construção de um amplo perfil dos municípios brasileiros no que
toca, principalmente, às suas administrações públicas; e propiciar a
elaboração de um quadro geral dos aspectos da gestão municipal na
atualidade brasileira em que os municípios vêm desempenhando papel cada
vez mais importante na implantação de diversas políticas setoriais" (IBGE,
2005, p.15).

Os municípios brasileiros constituem a unidade de investigação da MUNIC, sendo os órgãos das administrações direta e indireta das prefeituras os principais informantes. Também o instrumento de coleta é único para todos os municípios e organizado em cadernos setoriais para facilitar a aplicação. Os procedimentos de coleta, crítica e consistência das informações também são muito semelhantes àqueles adotados pela Fundação Seade na aplicação da PMU. Inicialmente, procura-se identificar um coordenador na prefeitura para agilizar o processo de coleta, os questionários são preenchidos pelos vários órgãos da prefeitura e, por ocasião do recolhimento, o técnico do IBGE realiza a primeira crítica dos dados coletados.

Em 2002, além do caderno de Gestão Pública, a MUNIC foi a campo com um suplemento sobre Meio Ambiente, com o objetivo de

\footnotetext{
"traçar um perfil dos municípios brasileiros concernente à gestão e ao estado do meio ambiente local, oferecendo subsídios à formulação de políticas públicas voltadas a um novo padrão de desenvolvimento sustentável" (IBGE, 2005, p.9).
}

Quanto ao processo de disponibilização, o IBGE adota uma política ampla de divulgação dos resultados da pesquisa. Para divulgar as informações da 
MUNIC 2002, foram produzidas duas publicações impressas, também disponibilizadas na página do IBGE na Internet, no sítio Perfil dos Municípios Brasileiros, sendo uma relativa ao questionário de Gestão e outra sobre o de Meio Ambiente. As duas publicações obedecem à mesma organização editorial, contendo informações necessárias ao entendimento e uso dos resultados da pesquisa: textos analíticos, tabelas com resultados, reprodução do instrumento de coleta (Figura 6) e base de dados.

No capítulo Notas Técnicas são apresentados os objetivos e as metodologias para aplicação da MUNIC 2002 e também são descritos os conteúdos dos questionários e o processo de apuração que abrange os procedimentos de checagem de consistência das informações coletadas.

Os textos analíticos referem-se a

"diversos temas abordados pela pesquisa em que são destacados os aspectos considerados mais relevantes pelos analistas que trabalharam nas diversas fases da pesquisa" (IBGE, 2005, p.20).

Gráficos com informações por Estado (Figura 7), tabelas e mapas (Figura 8) ilustram e complementam os textos.

Em seguida, é apresentado um conjunto amplo de tabelas organizadas por temas que incorporam grande parte das variáveis com informações segundo faixas de tamanho populacional dos municípios, grandes regiões e unidades da federação (Figura 9).

Através destes conjuntos de textos e tabelas, a instituição apresenta uma visão geral dos resultados da pesquisa, possibilitando também 0 entendimento e a interpretação de aspectos relevantes dos temas abordados, além de auxiliar na disseminação dos resultados da pesquisa para a sociedade em geral.

Anexado à publicação, o IBGE disponibiliza um CD-ROM, contendo a base de dados em formato de planilha Excel e com as variáveis organizadas por temas e segundo municípios. As informações por variáveis são recuperadas com facilidade, porém, como o Excel não é um software de banco de dados, o usuário 
encontra dificuldades para construir novas tabelas, fazer cruzamentos de variáveis, etc.

A recuperação da informação na Internet é feita através de aplicativo. Para iniciar a pesquisa o usuário deve selecionar uma unidade da federação e, em seguida, um município, na lista organizada em ordem alfabética. Após a seleção de um tema, deve-se escolher um subtema. O resultado da busca é visualizado em forma de tabela, com informações para todas as variáveis correspondentes ao subtema e município escolhido, sendo esta a única forma de recuperação dos dados (Figura 10).

Também no caso da MUNIC, as bases de dados disponibilizadas tanto na Internet como as planilhas no CD-ROM possuem a mesma estrutura e organização da base resultante da pesquisa de campo, o que gera os mesmos problemas identificados na PMU, ou seja, planilhas com informações repetitivas e desnecessárias, conforme ilustram os exemplos das Figuras 6 e 10. 
FIGURA 6 - Tela do Suplemento de Meio Ambiente - Bloco sobre Agenda 21 MUNIC 2002

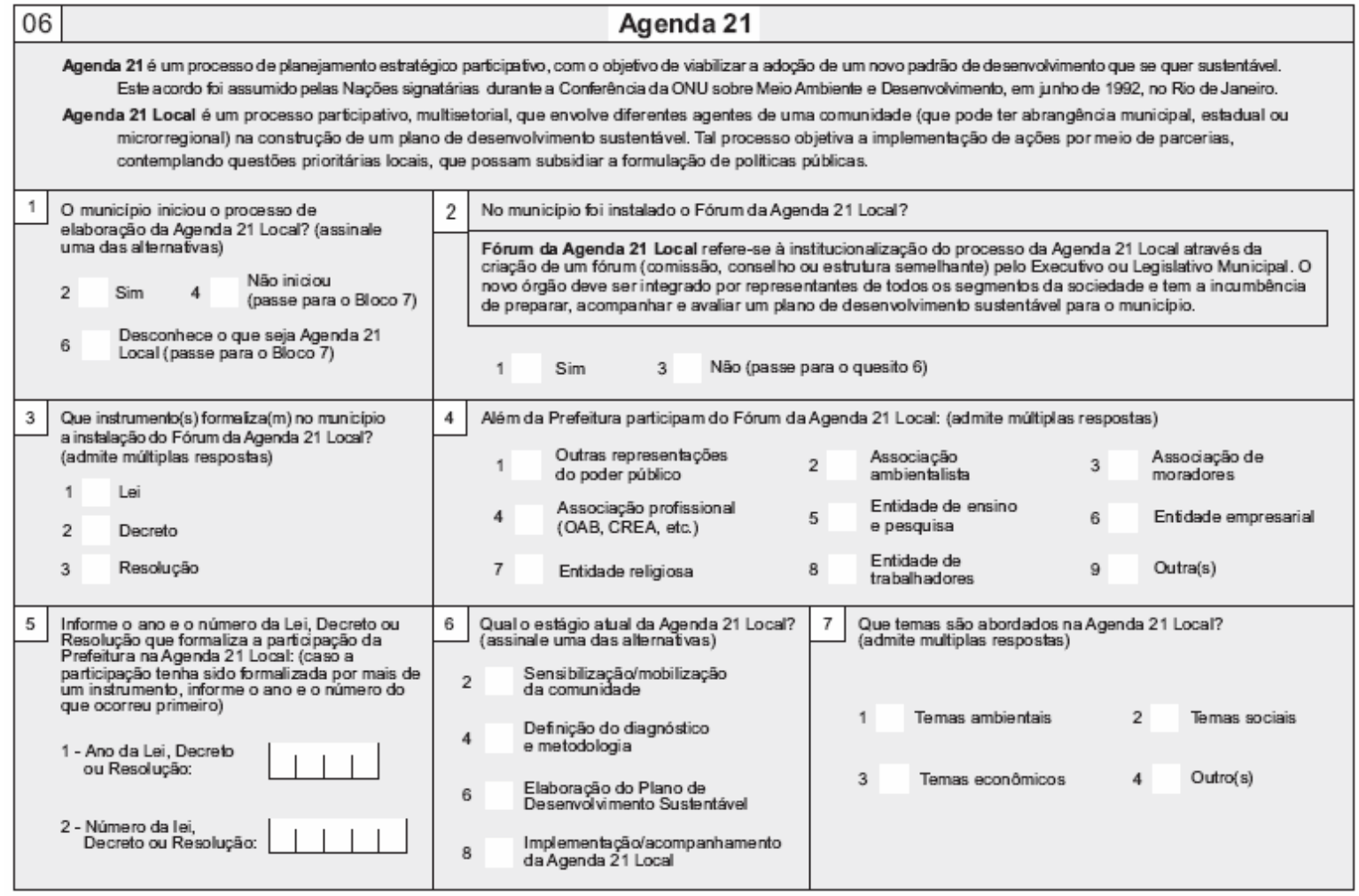

FIGURA 7 - Informações sobre o subtema Agenda 21 agregadas por Unidades da Federação e disponibilizadas no site "Perfil dos Municípios Brasileiros" do IBGE

Gráfico 20 - Proporção de municipios que iniciaram o processo de Agenda 21, por Unidades da Federação - 2002

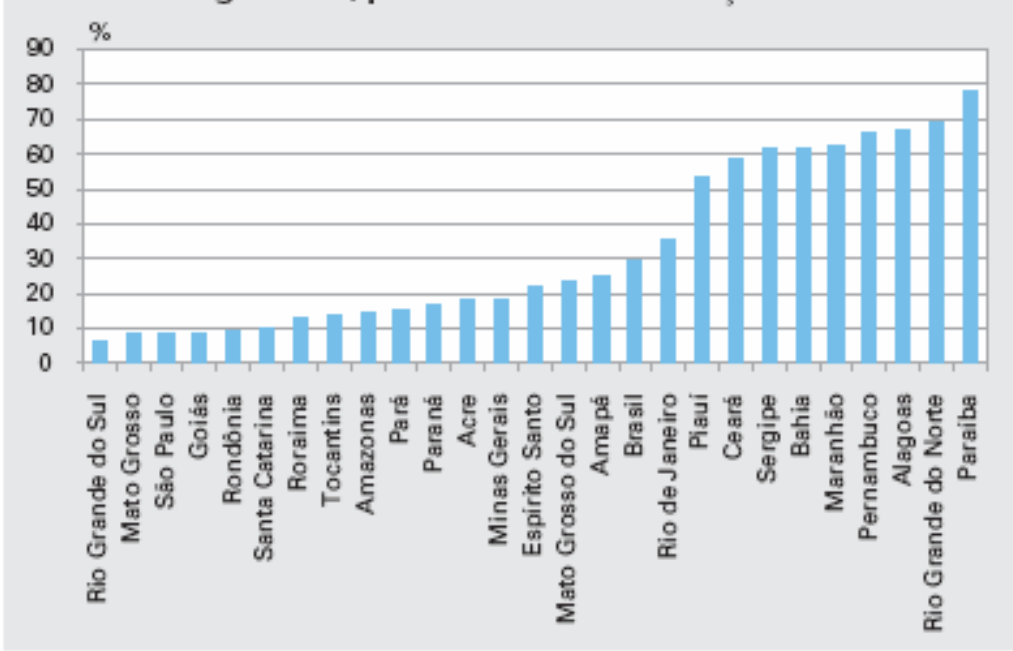

Fonte: IBGE, Diretoria de Pesquisas, Coordenação de População e Indicadores Sociais, Pesquisa de Informaçóes Básicas Municipais 2002. 
FIGURA 8 - Informações georreferenciadas sobre o subtema Agenda 21 e disponibilizadas no site "Perfil dos Municípios Brasileiros" do IBGE

Mapa 1 - Situação dos municípios quanto ao estágio da Agenda 21 Local - Brasil - 2002

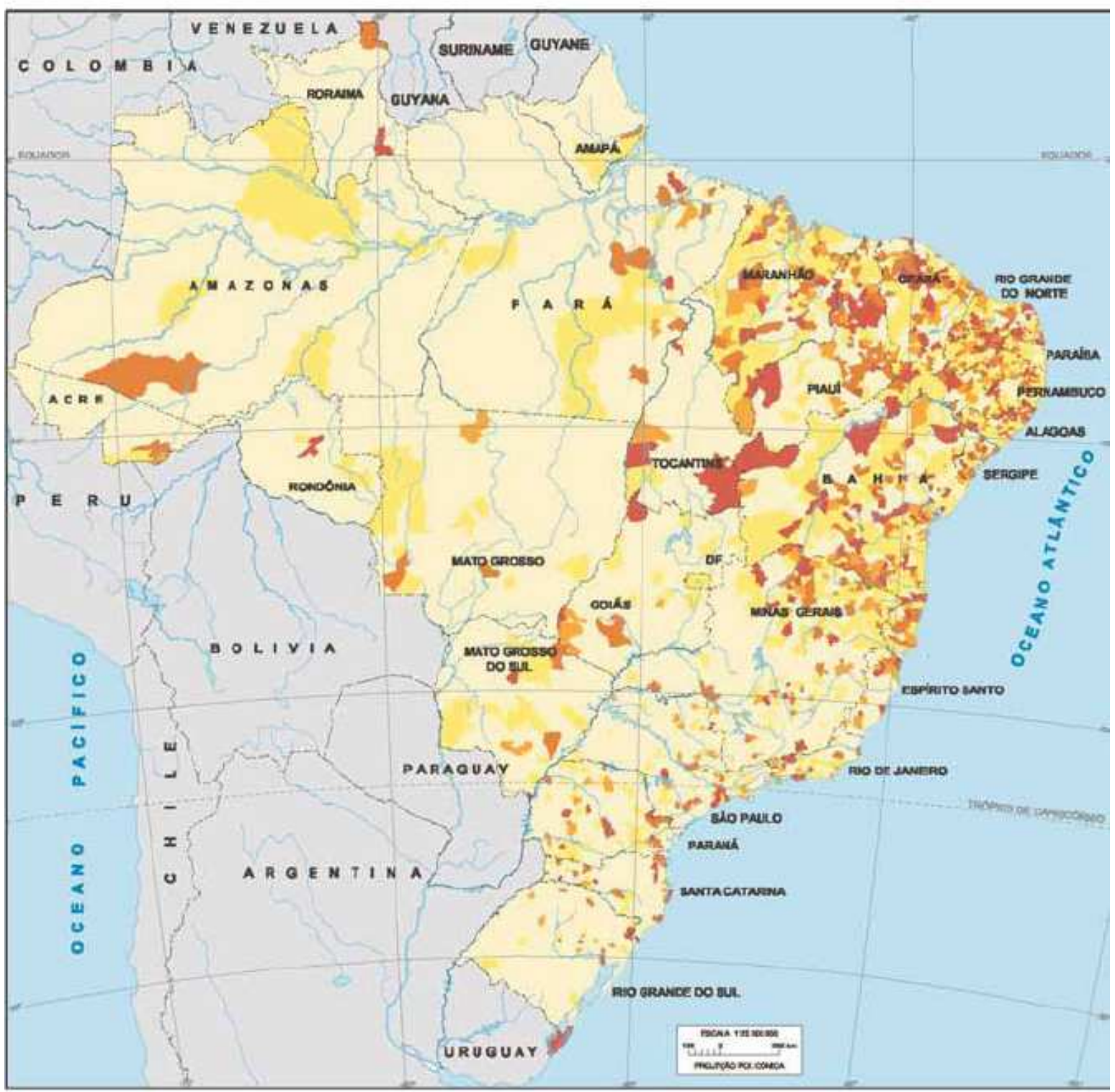

Situaçăo dos municipios quanto ao estágio da Agenda 21 Local

Número de municipios

Năo iniciou ou nåo sabe o que á a Agenda 21 Local

3.905

Sensibilizagăo/mobilizaçăo de comunidade

Definiçẩo do diagnostico e metodologia

826

Elaboraçato do Plano de Desenvolvimento Sustentável

213

Implementaçăolecompanhamento da Agenda 21 Local

357

256 
FIGURA 9 - Informações sobre o subtema Agenda 21 organizadas em tabela Excel e disponibilizadas no site "Perfil dos Municípios Brasileiros" do IBGE

Tabela 8 - Municípios, total e com existência de Agenda 21 local, com indicação de algumas características e temas abordados na Agenda 21 local, segundo classes de tamanho da população,

Grandes Regiões e Unidades da Federação - 2002

\begin{tabular}{|c|c|c|c|c|c|c|c|c|}
\hline \multirow{4}{*}{$\begin{array}{c}\text { Classes de tamanho da população, } \\
\text { Grandes Regiões e } \\
\text { Unidades da Federação }\end{array}$} & \multicolumn{8}{|c|}{ Municípios } \\
\hline & \multirow{3}{*}{$\begin{array}{c}\text { Total } \\
\text { (1) }\end{array}$} & \multicolumn{7}{|c|}{ Com existência de Agenda 21 local e algumas características (2) } \\
\hline & & $\begin{array}{c}\text { Processo } \\
\text { de } \\
\text { elaboração }\end{array}$ & & & \multicolumn{4}{|c|}{ Estágio atual } \\
\hline & & Iniciado & $\begin{array}{c}\text { Não } \\
\text { iniciado }\end{array}$ & $\begin{array}{c}\text { Desco- } \\
\text { nhecem } \\
\text { o que seja } \\
\text { Agenda } 21 \\
\text { local }\end{array}$ & $\begin{array}{c}\text { Sensi- } \\
\text { bilização/ } \\
\text { mobili- } \\
\text { zação da } \\
\text { comuni- } \\
\text { dade }\end{array}$ & $\begin{array}{l}\text { Definição } \\
\text { do diag- } \\
\text { nóstico } \\
\text { e meto- } \\
\text { dologia }\end{array}$ & \begin{tabular}{|c|} 
Elabo- \\
ração \\
do plano \\
de desen- \\
volvimento \\
sustentável
\end{tabular} & $\begin{array}{c}\text { Imple- } \\
\text { mentação/ } \\
\text { acompa- } \\
\text { nhamento }\end{array}$ \\
\hline Total & 5560 & 1652 & 3329 & 576 & 826 & 213 & 357 & 256 \\
\hline \multicolumn{9}{|l|}{ Classes de tamanho da população } \\
\hline Até 5000 & 1371 & 226 & 926 & 219 & 103 & 27 & 54 & 42 \\
\hline De $\quad 5001$ a 20000 & 2666 & 830 & 1553 & 281 & 422 & 97 & 189 & 122 \\
\hline De 20001 a 100000 & 1292 & 482 & 735 & 74 & 251 & 66 & 94 & 71 \\
\hline De 100001 a 500000 & 198 & 91 & 105 & 2 & 40 & 17 & 19 & 15 \\
\hline Mais de 500000 & 33 & 23 & 10 & - & 10 & 6 & 1 & 6 \\
\hline \multicolumn{9}{|l|}{ Grandes Regiões e Unidades da Federação } \\
\hline Norte & 449 & 65 & 309 & 74 & 26 & 4 & 14 & 21 \\
\hline Rondônia & 52 & 5 & 32 & 14 & 3 & - & - & 2 \\
\hline Acre & 22 & 4 & 10 & 8 & 2 & 1 & 1 & - \\
\hline Amazonas & 62 & 9 & 38 & 15 & 7 & - & 2 & - \\
\hline Roraima & 15 & 2 & 11 & 2 & - & - & 1 & 1 \\
\hline Pará & 143 & 22 & 109 & 12 & 9 & 2 & 9 & 2 \\
\hline Amapá & 16 & 4 & 12 & - & 3 & - & 1 & - \\
\hline Tocantins & 139 & 19 & 97 & 23 & 2 & 1 & - & 16 \\
\hline Nordeste & 1792 & 1144 & 590 & 56 & 549 & 137 & 279 & 179 \\
\hline Maranhão & 217 & 136 & 75 & 6 & 83 & 17 & 24 & 12 \\
\hline Piauí & 222 & 118 & 93 & 11 & 34 & 12 & 51 & 21 \\
\hline Ceará & 184 & 108 & 65 & 10 & 39 & 21 & 26 & 22 \\
\hline Rio Grande do Norte & 167 & 115 & 45 & 6 & 33 & 10 & 40 & 32 \\
\hline Paraíba & 223 & 174 & 47 & 2 & 103 & 24 & 35 & 12 \\
\hline Pernambuco & 185 & 123 & 61 & 1 & 70 & 10 & 26 & 17 \\
\hline Alagoas & 102 & 68 & 31 & 3 & 37 & 6 & 13 & 12 \\
\hline Sergipe & 75 & 46 & 24 & 5 & 13 & 7 & 19 & 7 \\
\hline Bahia & 417 & 256 & 149 & 12 & 137 & 30 & 45 & 44 \\
\hline Sudeste & 1668 & 263 & 1172 & 233 & 145 & 49 & 36 & 33 \\
\hline Minas Gerais & 853 & 156 & 568 & 129 & 96 & 19 & 24 & 17 \\
\hline Espírito Santo & 78 & 17 & 57 & 4 & 3 & 8 & 1 & 5 \\
\hline Rio de Janeiro & 92 & 33 & 53 & 6 & 20 & 7 & 2 & 4 \\
\hline São Paulo & 645 & 57 & 494 & 94 & 26 & 15 & 9 & 7 \\
\hline Sul & 1188 & 127 & 899 & 162 & 68 & 18 & 22 & 19 \\
\hline Paraná & 399 & 67 & 301 & 31 & 44 & 9 & 8 & 6 \\
\hline Santa Catarina & 293 & 30 & 237 & 26 & 11 & 3 & 10 & 6 \\
\hline Rio Grande do Sul & 496 & 30 & 361 & 105 & 13 & 6 & 4 & 7 \\
\hline Centro-Oeste & 463 & 53 & 359 & 51 & 38 & 5 & 6 & 4 \\
\hline Mato Grosso do Sul & 77 & 18 & 52 & 7 & 13 & 1 & 2 & 2 \\
\hline Mato Grosso & 139 & 12 & 105 & 22 & 9 & 1 & 2 & - \\
\hline Goiás & 246 & 22 & 202 & 22 & 15 & 3 & 2 & 2 \\
\hline Distrito Federal & 1 & 1 & - & - & 1 & - & - & - \\
\hline
\end{tabular}


FIGURA 10 - Resultado da busca de informações sobre o subtema Agenda 21 para o Município de Campinas no site "Perfil dos Municípios Brasileiros" do IBGE

\section{Agenda 21}

Foi Iniciado no município a elaboração da Agenda 21 local Não

Foi Instalado o Fórum da A21 Local

Não se aplica

Instrumento(s) que formalizou(aram) a Agenda21 local:

LEI

Não

DECRETO

Não

RESOLUÇÃO

Não

Entidades que participam do Fóruma da Agenda 21 local:

Outras representações Públicas

Não

Assoc Ambientalista

Não

Assoc de moradores

Não

Assoc Profissional (OABNão se aplicaCREA etc.)

Não

Entidade de ensino e pesquisa

Não

Entidade empresarial

Não

Entidade religiosa

Não

Entidade de trabalhadores

Não

Outras(s)

Não

Ano da lei que formalizou a Prefeitura na Agenda21 Local Não se aplica

Estágio atual da Agenda21 Local

Não se aplica

A21 Local aborda:

Temas ambientais

Não

Temas sociais

Não

Temas econômicos

Não

Outros temas

Não

Fonte: IBGE, Perfil dos Municípios Brasileiros - Meio Ambiente 2002 


\section{6 - A DISPONIBILIZAÇÃO DA INFORMAÇÃO SEGUNDO PARÂMETROS DOCUMENTÁRIOS}

Como visto anteriormente, o processo de produção de informações estatísticas e institucionais é complexo, abrange várias etapas e deve ser planejado de maneira integrada para que a informação coletada seja pertinente, tenha validade, utilidade e visibilidade.

A última etapa da pesquisa - a da disponibilidade - envolve a produção de sua documentação, o tratamento e a organização da base de dados para torná-la disponível ao usuário. Para que os objetivos relativos à utilidade e à visibilidade sejam atingidos, é importante estabelecer uma política ampla de divulgação e disponibilização dos resultados.

Essa política de disseminação deve contemplar dois processos distintos e complementares: o de divulgação dos resultados da pesquisa propriamente dita, para garantir sua visibilidade; e o de disponibilização da base de dados, de forma a permitir a recuperação das informações e a sua utilização por seus principais usuários - poder público, sociedade civil organizada e universidades.

No primeiro caso - o da divulgação dos resultados -, é importante a publicação de textos analíticos contendo os aspectos mais relevantes da pesquisa, bem como tabelas-sínteses, gráficos e mapas que complementem seus principais resultados. Os textos analíticos ajudam a disseminação junto à mídia e ao público em geral, permitindo melhor entendimento dos seus objetivos e apresentando a visão da instituição sobre o tema pesquisado. Essas informações também são importantes para atender à demanda por dados mais agregados e de abrangência estadual ou nacional.

Quanto ao processo de disponibilização, além da base de dados, é necessário tornar disponível a metodologia da pesquisa, compreendendo identificação dos seus objetivos, descrição dos procedimentos de coleta e de apuração da informação, definição das unidades de investigação, apresentação dos instrumentos de coleta e definição das variáveis disponibilizadas. Também devem ser identificados os condicionantes técnicos e as delimitações da pesquisa 
quanto ao período de referência, ao universo pesquisado, à abrangência geográfica e à definição do âmbito da pesquisa.

O conhecimento da metodologia da pesquisa amplia as possibilidades de exploração das bases de dados, a produção de estudos analíticos e a construção de novos cenários de estudos. Também tornam-se possíveis a comparabilidade e o confronto entre resultados de pesquisas similares e, como é o caso dos levantamentos socioeconômicos e institucionais, a construção de indicadores sociais através do cruzamento e a agregação de informações obtidas por diferentes pesquisas.

Originalmente, a base de dados resultante da etapa de campo da pesquisa apresenta com uma organização que segue a lógica do instrumento de coleta (Anexo), que tem por objetivo a captação e a consistência da informação. Para a disponibilização, no entanto, é necessário realizar procedimentos que permitam transformar os dados originais em informações passíveis de serem consultadas sem dificuldade. Essa operação requer o uso de recursos documentários, que compreendem tanto a reestruturação da base, como o tratamento das variáveis pesquisadas. Em todos os meios de divulgação, mas particularmente na Internet ou em CD-ROM, as bases de dados podem ter seu uso potencializado se forem criadas condições favoráveis para a recuperação da informação.

No item 3.2, foi visto que as LDs, metalinguagens construídas com o objetivo de estabelecer intermediação para viabilizar o acesso à informação, são elaboradas a partir de uma metodologia que pode ser aplicada para organização e recuperação de informações de bases de dados, entendendo-se por organização para disponibilização o processo que envolve o armazenamento e a recuperação da informação, com o objetivo principal de transmiti-la.

A aplicação dessa metodologia permite considerar várias alternativas de recuperação da informação, desde que esteja garantida a estruturação das informações por meio de um sistema de relações, condição para dar significado às informações. Em particular, as relacões hierárquicas, por natureza estruturantes, auxiliam a delimitação de temas e subtemas, segundo princípios de 
superordenação e subordinação e partilhamento de características. Em cada subtema, a aplicação dos mesmos princípios estruturantes permite acolher as variáveis caracterizadas pelo maior nível de desagregação.

O uso das noções estruturantes possibilita, na recuperação da informação por tema e, em seguida, por subtema, a identificação do conjunto de variáveis subordinadas. Na recuperação via tema pressupõe que o usuário saiba identificar o tema relativo à variável que deseja, ocasionando, por esse motivo, a necessidade de realizar inúmeras seleções. Do mesmo modo, a localização da variável pode exigir que o usuário percorra vários níveis da hierarquia. Esse problema, todavia, pode ser contornado se o sistema oferecer, também, um índice alfabético de variáveis. A aplicação das noções de estrutura lógico-semântica funciona, todavia, como um recurso didático para localização das variáveis existentes no sistema relativas a um determinado tema, ou seja, serve como meio de recuperar variáveis específicas.

À metodologia documentária, como também visto anteriormente, associa-se a metodologia terminológica, que, além de conferir referência concreta à delimitação do significado e precisão de um termo, dá as bases para a realização rigorosa da estruturação hierárquico-conceitual, agregando, por compartilhamento de características, os conceitos relacionados.

As normas documentárias também dão destaque às relações de associação entre os termos, podendo indicar as variáveis associadas. A aplicação desse princípio, embora seja prevista para co-relacionar os termos no interior da pesquisa, pode, também, ser feita de forma mais ampla, co-relacionando informações de bases diferentes e complementares, desde que sejam compatíveis quanto à abrangência geográfica e à periodicidade.

Nos casos da PMU e da MUNIC, a aplicação do princípio associativo pode ser utilizado para estabelecer relações que auxiliem o usuário na compreensão de determinados fenômenos, por meio de links a produtos externos, como, por exemplo, informações socioeconômicas e indicadores sociais de abrangência municipal (IPRS - Índice Paulista de responsabilidade Social, etc.), informações sobre caracterização do território (área do município, taxa de 
urbanização, etc.) e demográficas (população total, urbana e rural, taxa de crescimento anual da população, etc.). ${ }^{4}$ Entendemos que associar um conjunto amplo de informações complementares, permite a melhor compreensão dos fenômenos identificados pela pesquisa e conduz à formulação de análises e cenários consistentes. Essas associações, portanto, têm neste caso o papel de fornecer metainformações, auxiliando a compreensão dos dados da pesquisa em pauta.

Do ponto de vista da disponibilização, outros recursos podem ser utilizados para fornecer maior possibilidade de uso das informações. É o caso das denominadas variáveis categóricas, que permitem a obtenção de informações totalizadas para uma região de abrangência mais agregada. Pode-se citar, como exemplo, a variável "natureza jurídica da empresa operadora do sistema de abastecimento de água do município", que, embora não constitua um dado totalizável para o Estado - porque não é numérico - pode ser reorganizada de forma a identificar quantos municípios são operados por empresas com essa característica. Essa operação é válida para todas as alternativas que foram previstas no instrumento de coleta, como, por exemplo, administração direta da Prefeitura, empresa ou autarquia municipal, empresa privada, e empresa pública estadual (Sabesp).

A possibilidade de escolha da forma da visualização dos resultados da recuperação da informação também facilita a utilização dos dados da base disponibilizada. Deve ser prevista, além das visualizações das informações em formato de tabelas e gráficos, a possibilidade do uso de georreferenciamento das informações, opção que pode ser viável para a recuperação de todas as variáveis da base, inclusive as mais desagregadas. A construção de mapas através do processo de georreferenciamento das informações, assim como gráficos-sínteses, propicia a identificação e o entendimento dos principais resultados da pesquisa e auxilia os processos de análise.

\footnotetext{
${ }^{4}$ A Fundação Seade desenvolve produtos eletrônicos em CD-ROM com informações da PMU e bases de dados socioeconômicos para atender a convênios firmados com secretarias e órgãos estaduais.
} 
Do mesmo modo, a recuperação de informações em formato de tabela e a possibilidade de salvar os arquivos em softwares gerenciadores de planilhas dão ao usuário maior liberdade de trabalho, permitindo, por exemplo, a inclusão de novas informações, a construção de indicadores, etc. Todos esses recursos de acesso aumentam as possibilidades de uso das informações. No entanto, a organização estrutural dos dados é o principal instrumento para apresentar as informações e torná-las acessíveis de forma mais clara.

Com esse objetivo, propõe-se a reorganização da forma de apresentação dos dados obtidos a partir do questionário, estruturada segundo vínculos lógico-conceituais e pragmáticos. Essa solução pode ser tomada com uma matriz que, embora não constitua uma linguagem no mesmo sentido que a linguagem documentária, é um recurso que organiza a disponibilização dos dados a partir dos elementos que têm em comum. A matriz, por outro lado, permite o funcionamento do módulo de recuperação, a ser demonstrado a partir de exemplo. Todavia, a proposta deve ser analisada não como uma solução definitiva, mas sim como o embrião para o estabelecimento de uma linguagem de organização e de recuperação da informação. É o que se apresenta a seguir. 


\section{QUADRO 1 - ESTRUTURA DE ORGANIZAÇÃO}

Proposta para estrutura de organização hierarquizada para disponibilização da base de dados do tema Saneamento Básico / PMU 2003

\section{SISTEMA DE SANEAMENTO BÁSICO}

\subsection{Administração do Sistema de Saneamento Básico}

1.1.1 Número de funcionários alocados nos serviços de abastecimento de água e esgoto sanitário

\subsubsection{Número total}

1.1.1.2. Segundo a formação profissional

1.1.1.2.1 Nível superior

1.1.1.2.2 Técnicos de nível médio

1.1.1.2.3 Nível médio

1.1.1.2.4 Outros não especificados

\subsubsection{Segundo o tipo de atividade}

1.1.1.3.1 Funções administrativas

1.1.1.3.2 Área comercial

1.1.2 Informações georreferenciadas (GIS) para serviços de saneamento Existência

\subsection{Sistema de Abastecimento de Água}

1.2.1 Natureza jurídica da empresa operadora

1.2.2 Existência de programa de uso racional da água

1.2.3 Manancial de abastecimento de água

1.2.3.1 Tipo de manancial utilizado no abastecimento de água

1.2.3.1.1 Denominação geográfica do manancial

1.2.3.1.2 Contaminação do mancial

1. 2.3.1.3 Licença ou outorga - Existência

1.2.4 Captação e produção

1.2.4.1 Volume de água produzida $\left(\mathrm{em} 1.000 \mathrm{~m}^{3}\right)$ - média mensal

1.2.4.1.1 Captação total (superficial + subterrânea)

1.2.4.1.2 Captação superficial

1.2.4.1.3 Captação subterrânea

1.2.4.1.4 Outro município ou sistema produtor

1.2.4.2 Produção do sistema de abastecimento de água - capacidade nominal

1.2.4.3 Volume de água medida - média mensal $\left(\mathrm{em} 1.000 \mathrm{~m}^{3}\right)$

1.2.4.4 Volume de água faturada - média mensal (em $\left.1.000 \mathrm{~m}^{3}\right)$

\subsubsection{Armazenamento}

1.2.5.1 Número de reservatórios

1.2.5.2 Capacidade de reservação $\left(\mathrm{em} \mathrm{m}^{3}\right)$ 


\subsubsection{Tratamento e controle da qualidade da água}

1.2.6.1 Fluoretação da água tratada - existência

1.2.6.1.1 Fluoretação da água produzida - percentual

1.2.6.2 Metodologia para monitoramento da qualidade da água distribuída Existência

1.2.6.2.1 Análises bacteriológica - existência

1.2.6.2.1.1 Coliformes fecais - existência

1.2.6.2.1.1.1 Quantidade mínima de amostras requeridas

1.2.6.2.1.1.2 Quantidade de análises realizadas

1.2.6.2.1.1.3 Quantidade de análises fora do padrão

1.2.6.2.1.2 Coliformes totais - existência

1.2.6.2.1.2.1 Quantidade mínima de amostras requeridas

1.2.6.2.1.2.2 Quantidade de análises realizadas

1.2.6.2.1.2.3 Quantidade de análises fora do padrão

1.2.6.2.2 Análise físico-química - existência

1.2.6.2.2.1 Cloro residual livre - existência

1.2.6.2.2.1.1 Quantidade mínima de amostras requeridas

1.2.6.2.2.1.2 Quantidade de análises realizadas

1.2.6.2. 2 .1.3 Quantidade de análises fora do padrão

1.2.6.2.2.2 Cor - existência

1.2.6.2.2. 1 Quantidade mínima de amostras requeridas

1.2.6.2.2.2.2 Quantidade de análises realizadas

1.2.6.2.2.2.3 Quantidade de análises fora do padrão

1.2.6.2.2.3 Turbidez - existência

1.2.6.2.2.3.1 Quantidade mínima de amostras requeridas

1.2.6.2.2.3.2 Quantidade de análises realizadas

1.2.6.2.2.3.3 Quantidade de análises fora do padrão

1.2.6.2.2.4 PH - existência

1.2.6.2.2. 1 Quantidade mínima de amostras requeridas

1.2.6.2.2.4.2 Quantidade de análises realizadas

1.2.6.2.2.4.3 Quantidade de análises fora do padrão

\subsubsection{Atendimento do sistema de abastecimento de água}

1.2.7.1 Domicílios urbanos abastecidos com rede pública de distribuição de água - percentual

1.2.7.2 Economias do sistema de abastecimento de água

1.2.7.2.1 Número total de economias

1.2.7.2.2 Número de economias segundo categorias

1.2.7.2.2.1 Residencial

1.2.7.2.2.2 Comercial

1.2.7.2.2.3 Pública

1.2.7.2.2.4 Industrial

1.2.7.3 Ligações com hidrômetro do sistema de abastecimento de água

1.2.7.3.1 Número total de ligações com hidrômetro

1.2.7.3.2 Número de ligações com hidrômetro segundo categorias

1.2.7.3.2.1 Residencial

1.2.7.3.2.2 Comercial

1.2.7.3.2.3 Pública

1.2.7.3.2.4 Industrial 
1.2.7.4 Ligações do sistema de abastecimento de água

1.2.7.4.1 Número total de ligações

1.2.7.4.2 Número de ligações segundo categorias

1.2.7.4.2.1 Residencial

1.2.7.4.2.2 Comercial

1.2.7.4.2.3 Pública

1.2.7.4.2.4 Industrial

1.2.7.5 Extensões relativas ao sistema de abastecimento de água

1.2.7.5.1 Extensão da rede (em quilômetros)

1.2.7.5.2 Extensão das adutoras (em metros)

\subsection{Sistema de Esgoto Sanitário}

1.3.1 Sistema de esgoto sanitário - existência

\subsubsection{Natureza jurídica da empresa operadora}

\subsubsection{Atendimento do sistema de esgoto sanitário}

1.3.3.1 Domicílios urbanos servidos com rede pública de esgotamento sanitário - porcentual

1.3.3.2 Economias do sistema de esgoto sanitário

1.3.3.2.1 Número total de economias

1.3.3.2.2 Número de economias segundo categorias

1.3.3.2.2.1 Residencial

1.3.3.2.2.2 Comercial

1.3.3.2.2.3 Pública

1.3.3.2.2.4 Industrial

1.3.3.3 Ligações do sistema de esgoto sanitário

1.3.3.3.1 Número total de ligações

1.3.3.3.2 Número de ligações segundo categorias

1.3.3.3.2.1 Residencial

1.3.3.3.2.2 Comercial

1.3.3.3.2.3 Pública

1.3.3.3.2.4 Industrial

1.3.3.4 Extensões relativas ao sistema de esgotamento sanitário 1.3.3.4.1 Extensão da rede (em quilômetros)

1.3.3.4.2 Extensão dos coletores-tronco (em metros)

1.3.3.4.3 Extensão dos interceptores (em metros)

1.3.3.4.4 Extensão dos emissários (em metros)

\subsubsection{Volume de esgoto sanitário lançado}

1.3.4.1 Volume de esgoto coletado - média mensal (em $\left.1.000 \mathrm{~m}^{3}\right)$

1.3.4.2 Volume faturado de esgoto - média mensal (em $\left.1.000 \mathrm{~m}^{3}\right)$

\subsubsection{Tratamento do esgoto sanitário}

1.3.5.1 Tratamento do esgoto sanitário - existência (mesmo que parcial)

1.3.5.2 Ligações do sistema de esgotamento sanitário - percentual que recebem algum tratamento 
1.3.5.3 Tratamento de esgoto sanitário - percentual segundo o nível de tratamento

1.3.5.3.1 Sem tratamento

1.3.5.3.2 Com tratamento primário

1.3.5.3.3 Com tratamento secundário

1.3.5.3.4 Com tratamento terciário

1.3.5.4 Tipo(s) de tratamento dispensado ao esgoto sanitário do município percentual em relação ao total do esgoto lançado

1.3.5.4.1 Sem tratamento

1.3.5.4.2 Gradeamento e/ou caixa de areia

1.3.5.4.3 Valo de oxidação

1.3.5.4.4 Fossa séptica

1.3.5.4.5 Filtro anaeróbico

1.3.5.4.6 Lagoa de estabilização

1.3.5.4.7 Lagoa aerada

1.3.5.4.8 Reatores anaeróbicos

1.3.5.4.9 Lodos ativados

1.3.5.4.10 "Outros"

1.3.5.5 Estações de tratamento de esgoto - existência

1.3.5.5.1 Em operação - existência

1.3.5.5.1.1 Quantidade

1.3.5.5.1.2 Vazão de lançamento (I/s)

1.3.5.5.1.3 Habitantes beneficiados

1.3.5.5.2 Em implantação - existência

1.3.5.5.2.1 Quantidade

1.3.5.5.2.2 Vazão de lançamento (I/s)

1.3.5.5.2.3 Habitantes beneficiados

1.3.5.5.3 Paralisadas - existência

1.3.5.5.3.1 Quantidade

1.3.5.5.3.2 Vazão de lançamento (I/s)

1.3.5.5.3.3 Habitantes beneficiados

1.3.5.6 Sistema de tratamento de esgoto sanitário - capacidade nominal de tratamento (em $\left.1.000 \mathrm{~m}^{3} / \mathrm{mês}\right)$ 


\section{QUADRO 2 - RECUPERAÇÃO POR TEMA}

Exemplos de recuperação das informações disponibilizadas, por tema e subtema, na estrutura proposta.

$1^{a}$ Opção - Seleção do conjunto de variáveis que compõem o $3^{\circ}$ nível da estrutura hierarquia

Seleção do $1^{\circ}$ nível hierárquico: Sistema de Saneamento Básico

\section{SISTEMA DE SANEAMENTO BÁSICO}

\subsection{Administração do Sistema de Saneamento Básico \\ 1.2. Sistema de Abastecimento de Água}

Seleção do $2^{\circ}$ nível hierárquico: administração do Sistema de Saneamento Básico

\section{SISTEMA DE SANEAMENTO BÁSICO}

\subsection{Administração do Sistema de Saneamento Básico}

1.1.1. Número de funcionários alocados nos serviços de abastecimento de água e esgoto sanitário

1.1.2. Informações georreferenciadas (GIS) para serviços de saneamento existência

Seleção do $3^{\circ}$ nível hierárquico: número de funcionários alocados nos serviços de abastecimento de água e esgoto sanitário

\section{SISTEMA DE SANEAMENTO BÁSICO}

\subsection{Administração do Sistema de Saneamento Básico}

1.1.1. Número de funcionários alocados nos serviços de abastecimento de água e esgoto sanitário

\subsubsection{Número total}

1.1.1.2. Segundo a formação profissional

1.1.1.2.1 Nível superior

1.1.1.2.2 Técnicos de nível médio

1.1.1.2.3 Nível médio

1.1.1.2.4 Outros não especificados

1.1.1.3. Segundo o tipo de atividade

1.1.1.3.1 Funções administrativas

1.1.1.3.2 Área comercial 
Resultado da pesquisa quando selecionado o conjunto de variáveis referentes ao número de funcionários alocados nos serviços de abastecimento de água e esgoto sanitário.

Número total de funcionários alocados nos serviços de abastecimento de água e esgoto sanitário.

Número de funcionários alocados nos serviços de abastecimento de água e esgoto sanitário segundo a formação profissional - nível superior

Número de funcionários alocados nos serviços de abastecimento de água e esgoto sanitário segundo a formação profissional - técnicos de nível médio

Número de funcionários alocados nos serviços de abastecimento de água e esgoto sanitário segundo a formação profissional - nível médio

Número de funcionários alocados nos serviços de abastecimento de água e esgoto sanitário segundo a formação profissional - outros não especificados

Número de funcionários alocados nos serviços de abastecimento de água e esgoto sanitário segundo o tipo de atividade - funções administrativas

Número de funcionários alocados nos serviços de abastecimento de água e esgoto sanitário segundo o tipo de atividade - área comercial

$2^{a}$ Opção - Seleção do conjunto de variáveis que compõem o $4^{\circ}$ nível da estrutura hierarquia: número de funcionários alocados nos serviços de abastecimento de água e esgoto sanitário, segundo a formação profissional.

\section{SISTEMA DE SANEAMENTO BÁSICO}

\subsection{Administração do Sistema de Saneamento Básico}

1.1.1. Número de funcionários alocados nos serviços de abastecimento de água e esgoto sanitário

\subsubsection{Segundo a formação profissional}

\subsection{Nível superior}

1.1.1.2.2 Técnicos de nível médio

1.1.1.2.3 Nível médio

1.1.1.2.4 Outros não especificados 
Resultado da pesquisa quando selecionado o conjunto de variáveis referentes ao número de funcionários alocados nos serviços de abastecimento de água e esgoto sanitário segundo a formação profissional.

Número de funcionários alocados nos serviços de abastecimento de água e esgoto sanitário segundo a formação profissional - nível superior

Número de funcionários alocados nos serviços de abastecimento de água e esgoto sanitário segundo a formação profissional - técnicos de nível médio

Número de funcionários alocados nos serviços de abastecimento de água e esgoto sanitário segundo a formação profissional - nível médio

Número de funcionários alocados nos serviços de abastecimento de água e esgoto sanitário segundo a formação profissional - outros não especificados

$3^{a}$ Opção - Seleção da variável que compõe o $5^{\circ}$ nível da estrutura hierarquia: número de funcionários alocados nos serviços de abastecimento de água $\mathrm{e}$ esgoto sanitário, segundo a formação profissional - nível superior.

\section{SISTEMA DE SANEAMENTO BÁSICO}

\subsection{Administração do Sistema de Saneamento Básico}

1.1.1. Número de funcionários alocados nos serviços de abastecimento de água e esgoto sanitário

\subsubsection{Segundo a formação profissional}

1.1.1.2.1 Nível superior

Resultado da pesquisa quando selecionada apenas uma variável.

Número de funcionários alocados nos serviços de abastecimento de água e esgoto sanitário segundo a formação profissional - nível superior 


\section{QUADRO 3 - RECUPERAÇÃO POR ASSUNTO}

Exemplos de recuperação das informações disponibilizadas, por assunto.

Número de funcionários alocados nos serviços de abastecimento de água e esgoto sanitário segundo a formação profissional - nível superior

Saneamento básico

Administração do sistema de saneamento básico

Número de funcionários

Formação profissional

Educação superior

Recursos humanos

Natureza jurídica da empresa operadora do sistema de abastecimento de água

Saneamento básico

Abastecimento de água

Administração do sistema de abastecimento de água

Natureza jurídica

Empresa operadora

Volume de água produzida - média mensal - captação superficial

Saneamento básico

Abastecimento de água

Produção de água

Captação de água

Captação superficial de água

Volume de água

Capacidade de reservação do sistema de abastecimento de água (em $\mathrm{m} 3$ )

Saneamento básico

Abastecimento de água

Armazenamento de água

Capacidade de reservação

Capacidade de armazenamento 


\section{7- CONSIDERAÇÕES FINAIS}

A partir da década de 90, a ocorrência de duas situações simultâneas redirecionou - do papel para o meio eletrônico - a política de divulgação dos resultados das pesquisas realizadas pelos órgãos públicos: a primeira foi o contingenciamento de gastos imposto a esses órgãos, que resultou na redução drástica do número de publicações impressas; a segunda foi o acelerado desenvolvimento na área das Tecnologias de Informação e Comunicação - TICs, incluindo as redes de comunicações.

Não há dúvidas de que as tecnologias de informação têm causado grandes impactos nos processos de produção, armazenamento e transmissão das informações, resultando no crescimento significativo da sua demanda. Apesar do aumento da velocidade de transmissão, da ampliação do volume de informações disponibilizadas e da difusão de equipamentos e tecnologias que facilitam o acesso, a transmissão da informação, por si só, não se concretiza; ao contrário, exige investimentos na linguagem para garantir a transformação da informação em conhecimento. O uso das tecnologias deve, nesse sentido, ser associado à criação de condições para que os indivíduos consigam apropriar as informações.

Tendo em vista o uso da informação, outros aspectos devem ser ressaltados, além dos procedimentos para disponibilização, como, por exemplo, aqueles relativos ao tempo de obtenção e à atualização das informações. Para o uso efetivo da informação institucional ou estatística na gestão pública, tanto na formulação quanto no acompanhamento da implementação das políticas púbicas, são necessárias informações obtidas em tempo hábil e que tenham a garantia da continuidade de produção ao longo do tempo, de modo a permitir a formulação de séries históricas.

Outro aspecto importante a ser observado é a necessidade de políticas de divulgação das pesquisas institucionais que considerem as especificidades das mídias de divulgação. A linha editorial para publicações na Internet não pode ser a mesma para aquelas impressas, o que significaria desprezar recursos e potencialidades de disponibilização de informações. 
$\mathrm{Na}$ área da gestão pública, a demanda por informações tem sido cada vez maior em decorrência de um novo modelo de gestão centrado no planejamento e na avaliação da implementação de políticas públicas, principalmente na área social, bem como do crescimento dos controles das ações e dos gastos públicos. A adoção do modelo de gestão pública comprometida com resultados demanda a produção de indicadores para subsidiar as atividades de diagnóstico, monitoramento e avaliação, principalmente das ações voltadas para as políticas sociais. Portanto, a tomada de decisão é um processo contínuo que envolve etapas distintas e cada uma destas demanda um conjunto de informações e de indicadores específicos de diferentes naturezas. O desafio está na construção de sistemas de informações abrangentes, que permitam obter informações específicas para cada etapa do processo - formulação, monitoramento e avaliação das políticas públicas - e que mobilizem o Estado para o aperfeiçoarmento das metodologias de coleta, de tratamento e de recuperação da informação, objetivando a construção de indicadores.

Nas etapas de diagnóstico e formulação das políticas públicas, as informações produzidas pelas agências estatais de estatísticas, tais como os censos demográficos e as pesquisas amostrais, são as principais fontes para a construção de indicadores de diagnósticos. Por sua vez, procedimentos de sistematização das informações decorrentes dos registros administrativos produzidos pelos órgãos dos três níveis de governo - municipal, estadual e federal - também são extremamente úteis para a gestão das políticas setoriais, principalmente porque permitem a construção de indicadores de monitoramento, tendo em vista a ampla cobertura e periodicidade contínua dessas fontes de dados e facilidade de obtenção. Se em relação às grandes pesquisas os procedimentos de coleta, tratamento e divulgação podem ser considerados razoavelmente consistentes, há muito 0 que investir nas pesquisas administrativas de caráter local. A análise da PMU, ora realizada, permitiu verificar que existe uma diferença entre o produto da coleta, enquanto sistematização dos dados dos questionários, e as formas para sua disponibilização. Se a metodologia utilizada na coleta dos dados objetiva o rastreamento das informações, a disponibilização obedece a parâmetros de uso. 
Foi possível identificar, também, que as metodologias documentárias, principalmente as utilizadas para construção de linguagens documentárias, aliadas às metodologias terminológicas que apoiam a identificação dos sistemas de conceitos, são referenciais importantes para organização e recuperação das informações.

Em resumo, a análise efetuada mostrou que a produção e a recuperação são formuladas em linguagens distintas, e que uma política que vise o uso ampliado das informações deve, necessariamente, considerar as diferenças que as caracterizam.

Espera-se, enfim, que este trabalho possa contribuir para a reflexão dessas questões e acrescentar à discussão alguns critérios a serem observados no tratamento e na estruturação de base de informações institucionais e estatísticas para disseminação, bem como para verificar os procedimentos de organização de produtos para divulgação dos resultados. Ao se propor a estruturação das informações como meio de organizar o produto da coleta, espera-se contribuir para viabilizar a otimização do acesso e uso das informações pela sociedade. 


\title{
8 - REFERÊNCIAS BIBLIOGRÁFICAS
}

\begin{abstract}
AUSTIN, D.; DALE, P. Diretrizes para o estabelecimento e desenvolvimento de Tesauros Monolíngues. Trad. de Bianca A. Melo e rev. Lígia Maria Café de Miranda. Brasília, IBICT, SENAI, 1993.
\end{abstract}

BAITELLO JR., N. A sociedade da informação. São Paulo em Perspectiva, São Paulo, v.8, n.4, p.19-21, out./dez. 1994.

BARReto, A. A. A questão da informação. São Paulo em Perspectiva, São Paulo, v.8, n.4, p.3-8, out./dez. 1994.

A mudança estrutural no fluxo do conhecimento: a comunicação eletrônica. Ciência da Informação, Brasília, v.27, n.2, p. 122-127, maio/ago. 1998.

Os destinos da ciência da informação: entre o cristal e a chama. DataGramaZero: Revista de Ciência da Informação, Rio de Janeiro, n.zero, dez. 1999. Disponível em: http://www.dgz.org.br/dez99/F I art.htm.

Os agregados de informação: memórias, esquecimento e estoques de informações. DataGramaZero: Revista de Ciência da Informação, Rio de Janeiro, v.1, n.3, jun. 2000. Disponível em: http://www.dgz.org.br/jun00/F I art.htm.

BATTAGLIA, L. Cadastros e registros fundiários: a institucionalização do descontrole sobre o espaço no Brasil. Tese de Doutorado. São Paulo, Faculdade de Arquitetura e Urbanismo da Universidade São Paulo, 1995.

CASTELLS, M. A sociedade em rede. $4^{\text {a }}$ ed. São Paulo, Paz e Terra, p.21-86, 2000.

CINTRA, A.M.M.; TÁLAMO, M.F.G.M.; LARA, M.L.G.; KOBASHI, N.Y. Para entender as linguagens documentárias. São Paulo, Polis, APB, 72 p. 1994. 
Linguagens Documentárias e Terminologia. In: ALVES, I.M. A constituição da normalização terminológica no Brasil. São Paulo: FFL/CITRAT, 1996 (Cadernos de Terminologia, $n^{0} 1$ ).

DOWBOR, L. Informação para a cidadania e o desenvolvimento sustentável. Seminário Internacional "Indicadores sociais direcionados para inclusão social”, São Paulo, Ponticífia Universidade Católica de São Paulo, 2003.

FERREIRA, S. P. Produção e Disponibilização de Estatísticas, uma abordagem institucional. São Paulo em Perspectiva, São Paulo, v.17, n.3-4, p.17-25, jul./dez. 2003.

FUNDAÇÃO SISTEMA ESTADUAL DE ANÁlisE DE DADOS. Pesquisa Municipal Unificada - PMU. São Paulo, Fundação Seade, 2000. Disponível em http://www.seade.gov.br/produtos/pmu/index.php

GRACIOSO, L. de S. Disseminação de informações estatísticas no Brasil: práticas e políticas das agências estaduais de estatística. Ci. Inf. [on-line], v.32, n.2, p.69-76, maio/ago. 2003.

GUIZZARDI Filho, O. A produção de estatísticas com base em registros administrativos: controle e informação. Dissertação (Mestrado em Ciência da Comunicação). São Paulo, Escola de Comunicações e Artes da Universidade de São Paulo, 2004.

GUIZZARDI Filho, O. e CONTI, V. Produção e disseminação de informações socioeconômicas. Transinformação, Campinas, v.13, n.2, p. 43-54, 2001.

INSTITUTO BRASILEIRO DE GEOGRAFIA E ESTATÍSTICA, Ministério do Planejamento, Orçamento e Gestão. Pesquisa de Informações Básicas Municipais - Perfil dos Municípios Brasileiros - Meio Ambiente 2002, Rio de Janeiro, IBGE, 2005. Disponível em: http://www.ibge.gov.br/home/estatistica/economia/perfilmunic/meio a mbiente 2002/meio ambiente2002.pdf

JANNUZZI, P. M. Indicadores Sociais no Brasil, Campinas, SP, Alínea, 2001. 
JANNUZZI, P. M.; e GRACIOSO, L. de S. Produção e disseminação da informação estatística: agências estaduais no Brasil. São Paulo em Perspectiva, São Paulo, v.16, n.3, p.92-103, out./dez. 2002.

LARA, M. L. G. A Arquitetura de Sistemas de Informações Estatísticas na Internet. São Paulo em Perspectiva, São Paulo, v.12, n.4, p.99-104, out./dez. 1998.

Representação e linguagens documentárias: bases teóricometodológicas. Tese (Doutorado em Ciências da Comunicação). São Paulo, Escola de Comunicações e Artes da Universidade de São Paulo, 1999.

Elementos de Terminologia. Apostila para uso didático. São Paulo, Escola de Comunicações e Artes, Departamento de Biblioteconomia e Documentação, 2002.

LARA M. L. G.; CAMARGO, J. C. C.; e ROCHA, S. G. Informação estatística, informação para cidadania. São Paulo em Perspectiva, São Paulo, v.16, n.3, p.83-91, jul./set. 2002.

LARA M. L. G.; CONTI V. L. Disseminação da Informação e Usuários. São Paulo em Perspectiva, São Paulo, v.17, n.3-4, p.26-34, jul./dez. 2003.

LOPES, E. Fundamentos da lingüística contemporânea. São Paulo, Ed Cutrix, 1987.

LOW-BEER, J. D. O novo paradigma das políticas urbanas: a regulação dos serviços públicos - limites e alcances. Tese de Doutorado. São Paulo, Faculdade de Arquitetura e Urbanismo da Universidade de São Paulo, 2000.

MOUSINHO, P. de O. Indicadores de desenvolvimento sustentável: modelos internacionais e especificidades do Brasil. Dissertação de Mestrado. Rio de Janeiro, IBICT, Convênio CNPq/IBICT UFRJ/ECO, 2001. 
PORCARO, R. M. A informação estatística oficial na sociedade da informação: uma (des)construção. DataGramaZero: Revista de Ciência da Informação, Rio de Janeiro, v.2 n.2, abr. 2001. Disponível em: http://www.dgz.org.br/abr01/F I art.htm.

Implicações da "nova economia" para a mensuração estatística: desajustes conceituais e metodológicos. DataGramaZero: Revista de Ciência da Informação, Rio de Janeiro, v.3 n.4, ago. 2002. Disponível em: http://www.dgz.org.br/ago02/F I art.htm.

SARGER, J. C. La terminología, puente entre varios mundos. In: CABRÉ, M. T. La terminología: teoría, metodología, aplicaciones. Barcelona, Ed. Antartida, 1993.

SENRA, N. C. Informação estatística: demanda e oferta, uma questão de ordem.DataGramaZero: Revista de Ciência da Informação, Rio de Janeiro, v.1 n.3 jun. 2000. Disponível em: http://www.dgz.org.br/jun00/F I art.htm.

Regime e Política de Informação Estatística. São Paulo em Perspectiva, São Paulo, v.16, n.3, jul./set. 2002.

SMIT, J. W.; BARRETO, A. A. Ciência da Informação: base conceitual para a formação do profissional. In: VALENTIM, M. L. (Org). Formação do profissional da informação. São Paulo, Ed. Polis, p.9-23, 2002.

TÁLAMO, M.F.G.M. Linguagem Documentária. São Paulo, APB, 1997 (Ensaios APB, $\left.n^{\circ} 45\right)$

Terminologia e Documentação. TradTerm, São Paulo, v.7, 2001.

TÁLAMO, M.F.G.M., LARA, M.L.G.; KOBASHI, N.Y. Contribuição da terminologia para a elaboração de tesauros. Ciência da Informação, Brasília, v.21, n.3, p. 197-200, set./dez. 1992. 
9 - ANEXO - Questionário de Saneamento Básico / PMU 2003 


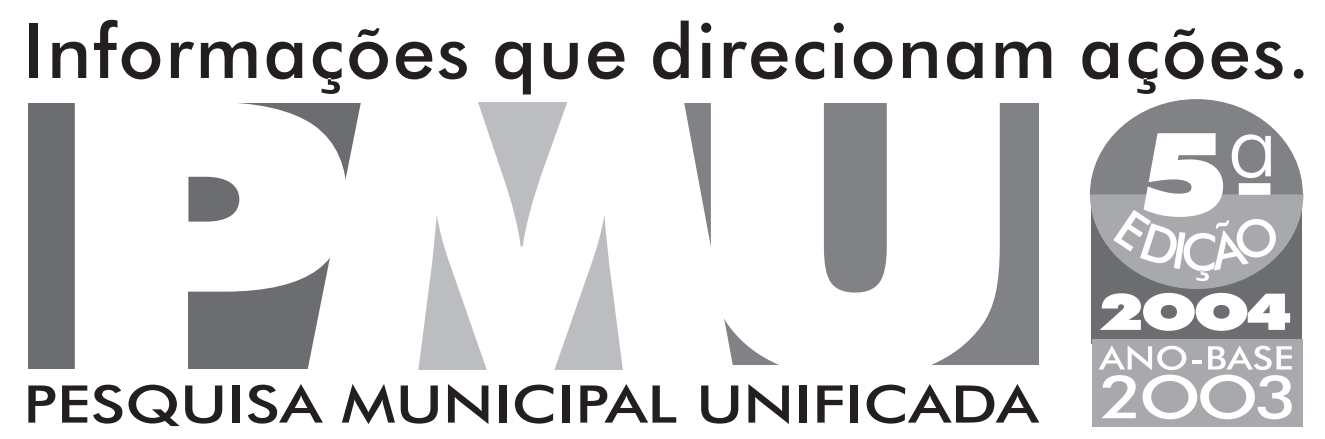

\section{SANEAMENTO BÁSICO}

Município

Secretaria de
Economia e

Planejamento

\section{SEADE}

Fundação Sistema Estadual de Análise de Dados 


\section{IEYIJ}

\section{SANEAMENTO BÁSICO}

1. ADMINISTRAÇÃO

2. SISTEMADE ABASTECIMENTO DE ÁGUA 7

3. SISTEMA DE ESGOTO SANITÁRIO 11

\section{SEADE}

Fundação Sistema Estadual de Análise de Dados

Fones (1 1) 3224-1744 / 3224-1775/3224-1783 Fax (1 1) 229-3531

e-mail:pmu@seade.gov.br

Avenida Cásper Líbero, 464 - 2andar

CEP 01033-000 São Paulo - SP 
Município

\section{Endereço da Prefeitura}

CEP Telefone (__ )

Fax (

E-mail

Horário de Expediente às

\section{RESPONSÁVEL PELAS INFORMAÇÕES FORNECIDAS}

Nome Legível

Cargo Expediente: manhã, das às tarde, das às

Setor/Divisão

Secretaria/Departamento

Endereço CEP

Telefone

Ramal $\operatorname{Fax}(\ldots)$

E-mail

Data do Preenchimento Assinatura

Se vários setores e/ou divisões colaboraram no preenchimento deste questionário, informar no quadro abaixo 0 nome das pessoas, setor e/ou divisão e as questões/itens respondidos.

Temas/Questões
Nome da Pessoa
Setor
Telefone 


\section{OBJETIVOS}

O objetivo deste questionário é coletar dados e informações acerca dos Sistemas Municipais de Saneamento Básico. A pesquisa abrange elementos sobre o sistema de captação e tratamento de água e o sistema de coleta e tratamento de esgotos, bem como 0 alcance de suas respectivas redes. Visa, ainda, obter subsídios para a compreensão dos impactos causados ao meio ambiente pela operação dos serviços de abastecimento de água e esgotamento sanitário.

As informações coletadas pela pesquisa terão grande valia para a organização de uma base de dados municipais, instrumento fundamental para diagnóstico da ação municipal, planejamento e execução de políticas públicas.

Certos de sua colaboração e interesse, agradecemos.

\section{INSTRUÇÕES PARA PREENCHIMENTO}

1. A responsabilidade pelas informações deverá ser do(s) órgão(s) responsável(is) pela área de Saneamento Básico no Município.

2. Leia o questionário todo antes de iniciar o seu preenchimento.

3. As informações deverão ser registradas a caneta azul ou preta, com letra legível.

4. Nenhuma questão deverá ficar em branco.

5. Observe as seguintes normas de preenchimento:

a) Para o preenchimento dos campos alfanuméricos (alternativas SIM ou NÃO), utilize sempre o número correspondente à alternativa de resposta. Quando a resposta for afirmativa (SIM), utilize o número $1 \mathrm{e}$, quando for negativa (NÃO), preencha o campo com o número 2.

Exemplo:3.1 - O Município possuía sistema de esgoto sanitário em 2003?

3001 |1 $1 \mathrm{SIM}$

$2 \mathrm{NÃO} \rightarrow$ Encerre o questionário

b) Nos campos reservados a valores numéricos, quando o fenômeno não existir anote o número zero (0).

c) Nos campos reservados a nomes, denominações ou quaisquer especificações, quando o fenômeno não existir anote traço (-).

6. Confira a soma das parcelas nos itens em que houver TOTAL.

7. Todas as informações deverão referir-se à posição em dezembro de 2003 , salvo instrução diferente na própria questão.

8. Se os campos existentes em determinadas questões forem insuficientes, complete as informações em cópias das respectivas questões e anote o número de folhas anexadas no espaço reservado à Complementação das Informações, no final do questionário. 
Atenção: Todas as informações fornecidas devem ser referentes ao total do Município, isto é, sede e distritos.

\section{ADMINISTRAÇÃO}

1.1.1- Indique, no quadro a seguir, a natureza jurídica da empresa operadora do sistema de saneamento básico no Município, em 2003.

\begin{tabular}{|c|c|c|}
\hline Natureza Jurídica & $\begin{array}{c}\text { Abastecimento } \\
\text { de Água } \\
1 \text { SIM } 2 \text { NÃO }\end{array}$ & $\begin{array}{c}\text { Esgoto } \\
\text { Sanitário } \\
1 \text { SIM } 2 \text { NÃO }\end{array}$ \\
\hline Administração direta da Prefeitura & $1001 \bigsqcup$ & $1002 \bigsqcup$ \\
\hline Empresa ou autarquia municipal & 1003 & 1004 \\
\hline Empresa privada & 1005 & 1006 \\
\hline Empresa pública estadual (Sabesp) & 1007 & 1008 \\
\hline
\end{tabular}

1.1.2- Caso tenha assinalado, na questão anterior, "empresa ou autarquia municipal" e/ou "empresa privada", indique sua(s) denominação(ões).

Empresa ou autarquia Municipal 1009

Empresa privada

1010

1.2- Indique o número de funcionários envolvidos na prestação dos serviços de abastecimento de água e esgotamento sanitário. Situação em 31/12/03.

Atenção: Os valores informados nos campos 1015 e 1019 devem ser iguais.

\subsection{1- Segundo a formação profissional}

Funcionários com nível superior

1011

Funcionários com formação de técnicos de nível médio

1012

Funcionários com nível médio (exclusive os técnicos)

1013

Demais funcionários (nível fundamental completo ou incompleto)

1014 
1.2.2- Segundo o tipo de atividade que exerce

Em funções administrativas

Em funções na área comercial

Em funções na área de operação e manutenção TOTAL DE FUNCIONÁRIOS

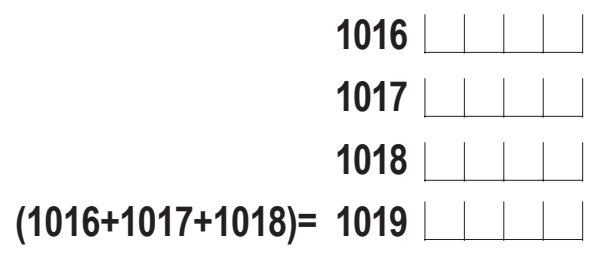

1.3- Existia, em 2003, um sistema de informações georreferenciadas (GIS) para os serviços de saneamento?

1020

$1 \mathrm{SIM}$

\section{2- SISTEMA DE ABASTECIMENTO DE ÁGUA}

2.0- Indique o percentual de domicílios urbanos abastecidos com rede pública de distribuição de água. Situação em 31/12/03.

2000 $\%$

2.1- Indique a situação dos mananciais de captação de água, relacionando o(s) tipo(s) de manancial(is) utilizado(s), forma(s) de contaminação e denominação geográfica.

Atenção: Utilize os códigos abaixo para o preenchimento dos campos "Código do tipo de manancial" e "Formas de contaminação". O campo "Denominação geográfica do manancial" somente deverá ser preenchido caso refira-se a manancial superficial, água proveniente de outro município e/ou sistema produtor. Nestes últimos casos, especifique o nome do(s) município(s) ou sistema(s) utilizado(s).

Se a lista for insuficiente faça quantas cópias forem necessárias e anexe-as ao questionário.

\section{CÓDIGOS DOS TIPOS DE MANANCIAIS UTILIZADOS:}

1 - Rio

2 - Lago

3 - Açude ou represa

4 - Ribeirão ou córrego

5 - Lagoa
6 - Poço profundo

7 - Mina ou fonte

8 - Poço raso

9 - Poço artesiano

10- Água proveniente de outro município e/ou sistema produtor Outro(s) (especifique)

112001

122002

\section{CÓDIGOS DAS FORMAS DE CONTAMINAÇÃO:}

A - Sem contaminação

B - Recebimento de esgoto sanitário

C - Recebimento de despejo industrial

D - Contaminação por outros cursos d'água
E - Contaminação causada por destinação inadequada de lixo

F - Contaminação por agrotóxicos

Outra(s) (especifique)

G 2003

H 2004 
Manancial $1 \rightarrow$ Código do tipo de manancial $\quad 2005\lfloor$

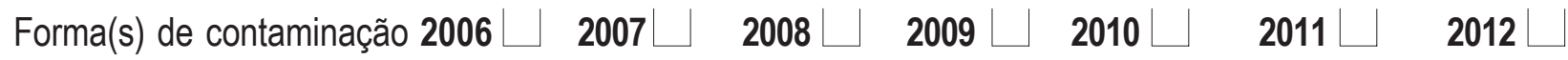

Denominação geográfica do manancial $\quad 2013\llcorner$

Existência de Licença ou Outorga (1-Sim; 2-Não): 2013a

Manancial $2 \rightarrow$ Código do tipo de manancial 2014

Forma(s) de contaminação $2015|-2016|-2017 \mid+2018$

Denominação geográfica do manancial 2022

Existência de Licença ou Outorga (1-Sim; 2-Não): 2022a

Manancial $3 \rightarrow$ Código do tipo de manancial 2023

Forma(s) de contaminação $2024 \bigsqcup 2025 \bigsqcup 2026 \bigsqcup 2027 \bigsqcup 2028 \bigsqcup \quad 2029 \bigsqcup \quad 2030 \bigsqcup$

Denominação geográfica do manancial 2031

Existência de Licença ou Outorga (1-Sim; 2-Não): 2031a

Manancial $4 \rightarrow$ Código do tipo de manancial $\quad 2032 L$

Forma(s) de contaminação $2033 \bigsqcup \quad 2034 \bigsqcup \quad 2035 \bigsqcup \quad 2036 \bigsqcup 2037\lfloor\quad 2038 \bigsqcup \quad 2039 \bigsqcup$

Denominação geográfica do manancial 2040 L

Existência de Licença ou Outorga (1-Sim; 2-Não): 2040a

Manancial $5 \quad \rightarrow \quad$ Código do tipo de manancial $\quad 2041 \bigsqcup \mid$

Forma(s) de contaminação $2042 \bigsqcup \quad 2043 \bigsqcup \quad 2044 \bigsqcup \quad 2045 \bigsqcup \quad 2046 \bigsqcup \quad 2047 \bigsqcup \quad 2048 \bigsqcup$

Denominação geográfica do manancial 2049

Existência de Licença ou Outorga (1-Sim; 2-Não): 2049a 
Manancial $6 \rightarrow$ Código do tipo de manancial $2050 \mathrm{~L}$

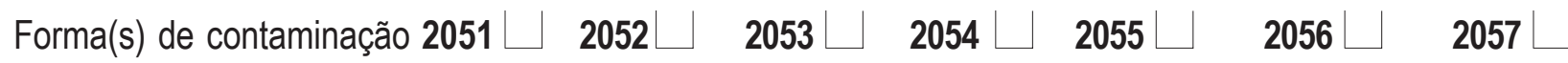

Denominação geográfica do manancial 2058

Existência de Licença ou Outorga (1-Sim; 2-Não): 2058a

2.2.1- Indique a média mensal do volume de água produzida (em $1.000 \mathrm{~m}^{3}$ ) no Município, de acordo com o tipo de captação, em 2003.

Atenção: Os valores devem ser informados em $1.000 \mathrm{~m}^{3}$, ou seja, os valores unitários devem ser divididos por 1.000 .

Captação superficial

Captação subterrânea

TOTAL
2059 $x 1.000 \mathrm{~m}^{3}$

2060 $x 1.000 \mathrm{~m}^{3}$

$2061 \downarrow+|+| \mid+\times 1.000 \mathrm{~m}^{3}$

2.2.2- Caso o Município seja abastecido por água proveniente de outro município ou sistema produtor, indique o volume médio mensal recebido (em $1.000 \mathrm{~m}^{3}$ ), em 2003.

Volume médio mensal recebido de outro município ou sistema produtor 2061a $\mathrm{x} 1.000 \mathrm{~m}^{3}$

2.3- Indique a capacidade nominal de produção (em $\left.1.000 \mathrm{~m}^{3} / \mathrm{mês}\right)$ do sistema de abastecimento de água do Município, em 2003.

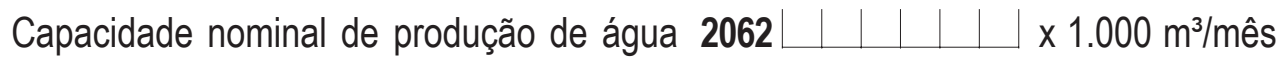

2.4- Indique a média mensal do volume de água medida e do volume de água faturada (em $1.000 \mathrm{~m}^{3}$ ), no Município, em 2003.

Volume medido $2063 \downarrow|+||| \times 1.000 \mathrm{~m}^{3} / \mathrm{mês}$

Volume faturado

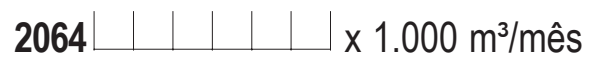

2.5.1- Existia fluoretação da água tratada pelo sistema de abastecimento de água do Município, em 2003 ? 2064a $\downarrow \quad 1$ SIM

$$
2 \text { NÃO } \rightarrow \text { Passe para a questão 2.6.1 }
$$


2.5.2- Indique o percentual de fluoretação da água produzida em 2003.

$2064 \mathrm{~b} \downarrow|| \downarrow \%$

2.6.1- Indique a existência de metodologia para monitoramento da qualidade da água distribuída à população do Município, em 2003.

Atenção: Atendendo à Portaria no 1.469, de 29/12/2000, que estabelece os procedimentos e responsabilidades relativos ao controle e vigilância da qualidade da água para consumo humano e seu padrão de potabilidade.

2064c $\bigsqcup 1$ SIM

$$
2 \text { NÃO } \rightarrow \text { Passe para a questão } 2.7
$$

2.6.2- Indique, segundo parâmetros selecionados, a quantidade mínima de amostras requeridas, bem como as quantidades de análises efetivamente realizadas e aquelas que se apresentaram como fora do padrão, relativas às análises bacteriológica e físico-química da água distribuída à população. Situação em 2003.

Parâmetros

Quantidades de Amostras e Análises

Amostras Mínimas Requeridas $\quad$ Realizadas $\quad$ Fora do Padrão

\section{Análise bacteriológica}

- Coliformes fecais

2064d

2064e

$2064 f$

- Coliformes totais

$2064 \mathrm{~g}$

2064h

2064i

Análise físico-química

Cloro residual livre

2064j

2064k

$2064 \mid$

Cor

$2064 \mathrm{~m}$

$2064 n$

20640

Turbidez

$2064 p \downarrow||||||$

$2064 q$

$2064 r$

$\mathrm{PH}$

2064s

$2064 t$

2064u

2.7- Indique o número de reservatórios do Município (enterrados, semi-enterrados e elevados) e a capacidade total de reservação $($ em m³). Situação em 31/12/03.

Atenção: Indicar a capacidade de reservação, somando todos os reservatórios do Município.

№ de reservatórios

Capacidade de reservação $\mathrm{m}^{3}$ 
2.8- Indique, no quadro a seguir, o número de economias, o número de ligações com hidrômetro e o total de ligações do sistema de abastecimento de água no Município. Situação em 31/12/03.

Atenção: Número de Economias - Unidade (casa, apartamento, loja, etc.) registrada como usuária.

Número de Ligações com Hidrômetro - Unidade, ou conjunto de unidades (prédios de apartamentos, prédios comerciais, etc.), registrada como usuária, cujo consumo de água é medido.

Número Total de Ligações - Unidade, ou conjunto de unidades (prédios de apartamentos, prédios comerciais, etc.), registrada como usuária, com ou sem medição de consumo.

Observar as diferenças de conceitos entre o número de economias e o total de ligações. Para que não haja dúvidas, cita-se um exemplo: um edifício residencial com 20 apartamentos deverá ser registrado como uma ligação e 20 economias.

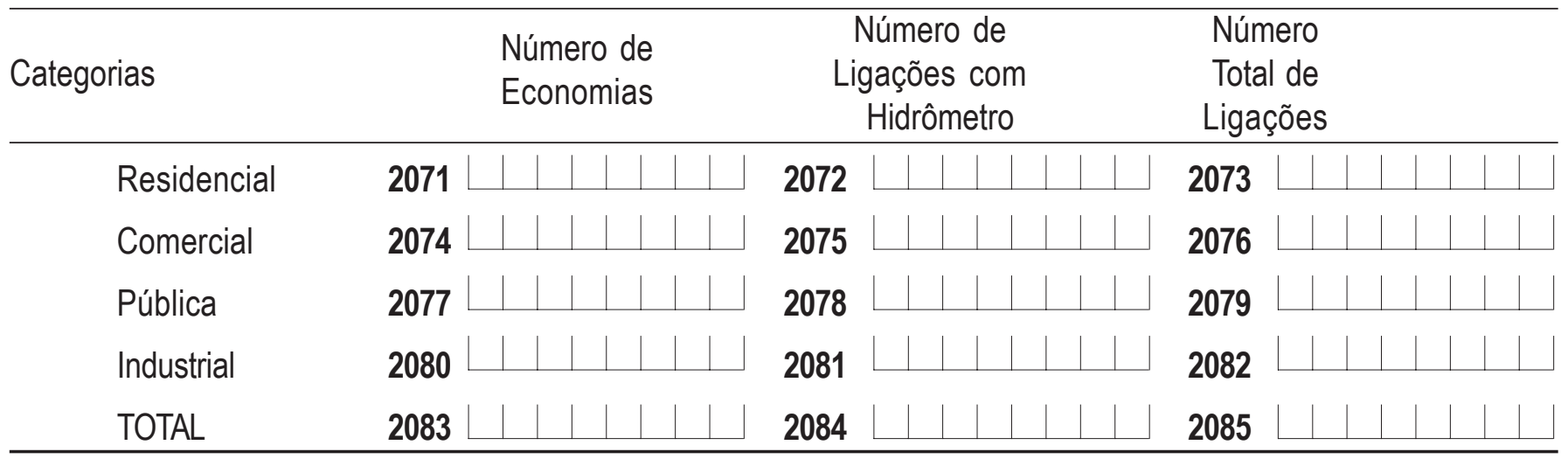

2.9- Indique as seguintes extensões, relativas ao sistema de abastecimento de água do Município. Situação em 31/12/03.

Rede (exceto ramais domiciliares) $2086\llcorner|+|||||$ quilômetros

Adutoras $\quad 2087\lfloor|||||| \mid$ metros

2.10- Existia, em 2003, Programa de Uso Racional da Água?

$2088 \sqcup 1$ SIM

2 NÃO 


\section{3- SISTEMA DE ESGOTO SANITÁRIO}

3.1.1- O Município possuía sistema de esgoto sanitário em 2003?

3001

$1 \mathrm{SIM}$

2 NÃO $\rightarrow$ Encerre o questionário

3.1.2- Indique o percentual de domicílios urbanos servidos com rede pública de esgotamento sanitário. Situação em 31/12/03.

3001a $\downarrow|| \downarrow \%$

3.2- Indique as seguintes extensões, relativas ao sistema de esgotamento sanitário do Município. Situação em 31/12/03.

Rede (exceto ramais domiciliares)

Coletores-tronco

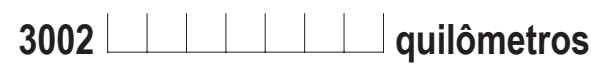

Interceptores

$3002 \mathrm{a} L|+|+||$ metros

Emissários

$3002 \mathrm{~b} L|+|||||$ metros

3002c $\llcorner|||||| \mid$ metros

3.3 - Indique a média mensal do volume de esgoto coletado (em $1.000 \mathrm{~m}^{3}$ ) no Município, em 2003.

Atenção: Volume de esgoto coletado é o volume médio de esgoto lançado na rede coletora, em geral calculado como sendo $80 \%$ do volume micromedido de água das economias com ligação de esgoto.

Volume de esgoto coletado

3003

$x 1.000 \mathrm{~m}^{3} / \mathrm{mês}$

3.4 - Indique a média mensal do volume faturado (ou cobrado) de esgoto (em 1.000 m³) no Município, em 2003.

Atenção: Volume de esgoto faturado é o volume médio de esgoto debitado ao total das economias, para fins de faturamento.

Volume faturado de esgoto

3004

$x 1.000 \mathrm{~m}^{3} / \mathrm{mês}$ 
3.5.1- Existia tratamento, mesmo que parcial, do esgoto sanitário do Município em 2003?

3005

1 SIM

2 NÃO $\rightarrow$ Passe para a questão 3.6

3.5.2- Indique o percentual de ligações do sistema de esgotamento sanitário que estavam interligadas a algum tipo de tratamento. Situação em 31/12/03.

3005a $\lfloor|| \mid \%$

3.5.3- Indique, no quadro a seguir, o percentual de esgoto tratado, segundo o nível de tratamento. Situação em 31/12/03.

Atenção: A soma dos percentuais por nível de tratamento mais a opção "Sem tratamento" deve necessariamente totalizar $100 \%$.

Níveis de

Percentual em

Tratamento

Relação ao Total

Sem tratamento

$3005 \mathbf{b} L|| \mid \%$

Tratamento primário

$3005 \mathrm{c}\llcorner|\downarrow| \%$

Tratamento secundário

3005d $\downarrow|\downarrow| \%$

Tratamento terciário

3005e $\downarrow \perp \mid \frac{\%}{\%}$ 
3.5.4- Indique, no quadro a seguir, o percentual que cada tipo de tratamento dispensado ao esgoto sanitário do Município representa em relação ao total do esgoto lançado. Situação em 31/12/03.

Atenção: A soma dos percentuais por tipo de tratamento mais a opção "Sem tratamento" deve necessariamente totalizar $100 \%$.

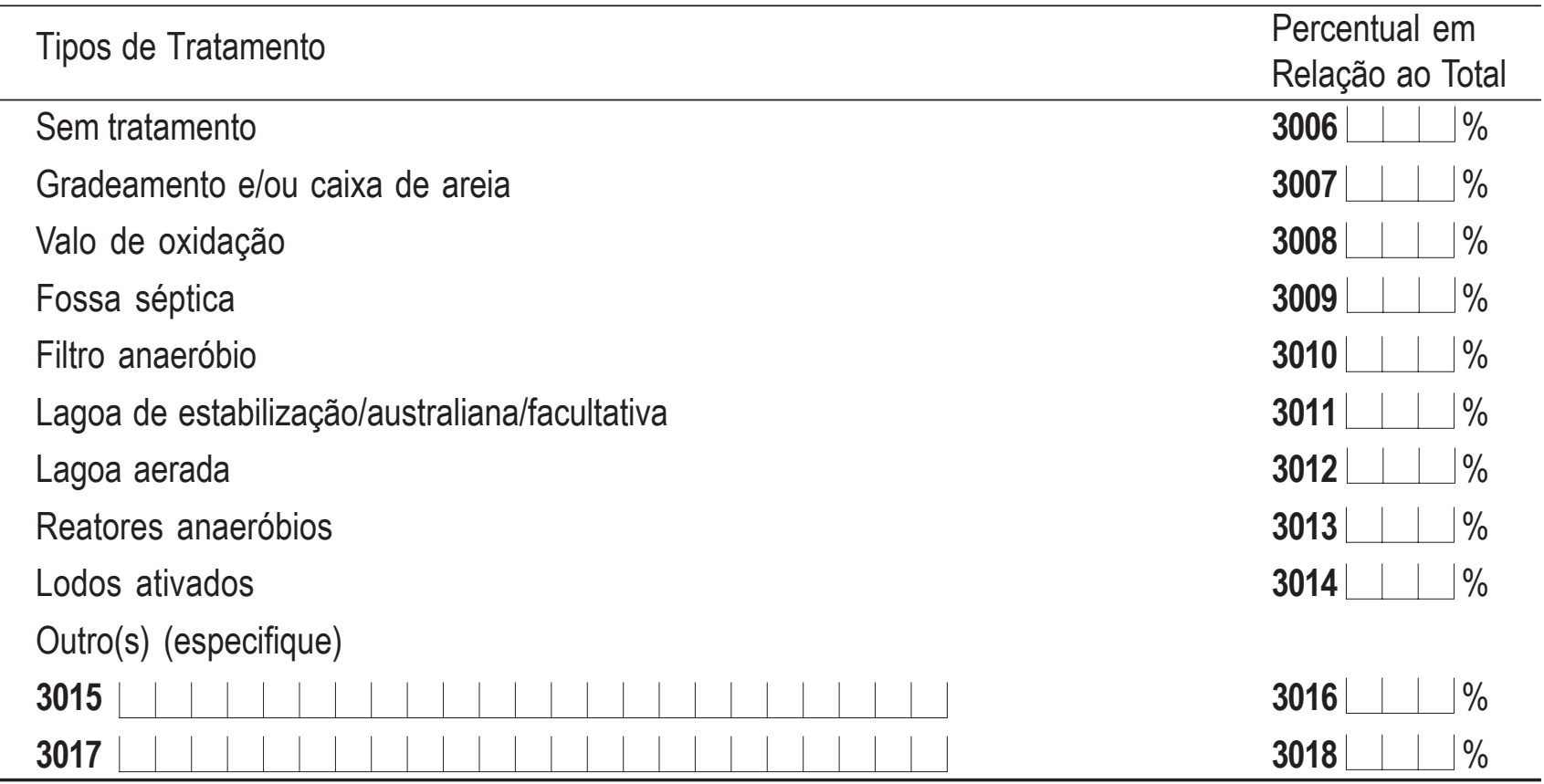

3.5.5- Indique o número de estações de tratamento de esgoto em operação, em implantação e paralisadas existentes no município. Situação em 31/12/03.

Atenção: Por estação de tratamento de esgoto entende-se toda e qualquer instalação destinada a tratar o esgoto coletado.

\begin{tabular}{|c|c|c|c|}
\hline Estações de Tratamento & Quantidade & $\begin{array}{c}\text { Vazão de } \\
\text { Lançamento (I/s) }\end{array}$ & $\begin{array}{c}\text { Habitantes Beneficiados } \\
\text { (estimativa) }\end{array}$ \\
\hline Em operação & 3019 & 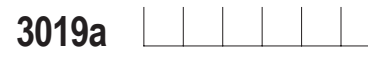 & $3019 b$ \\
\hline Em implantação & 3020 & 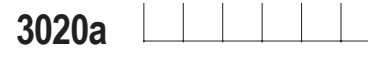 & $3020 b$ \\
\hline Paralisadas & 3021 & $3021 a$ & $3021 b$ \\
\hline
\end{tabular}


3.5.6- Indique a capacidade nominal de tratamento (em $1.000 \mathrm{~m}^{3} / \mathrm{mês}$ ) do sistema de tratamento de esgoto sanitário do Município, em 2003.

Capacidade nominal de tratamento do esgoto 3022 $1.000 \mathrm{~m}^{3} / \mathrm{mês}$

3.6- Indique, no quadro a seguir, o número de economias e o total de ligações do sistema de esgoto sanitário no Município. Situação em 31/12/03.

Atenção: Número de Economias - Unidade (casa, apartamento, loja, etc.) registrada como usuária.

Total de Ligações - Unidade, ou conjunto de unidades (prédios de apartamentos, prédios comerciais, etc.), registrada como usuária.

Observar as diferenças de conceitos entre o número de economias e o número total de ligações. Para que não haja dúvidas, cita-se um exemplo: um edifício residencial com 20 apartamentos deverá ser registrado como uma ligação e 20 economias.

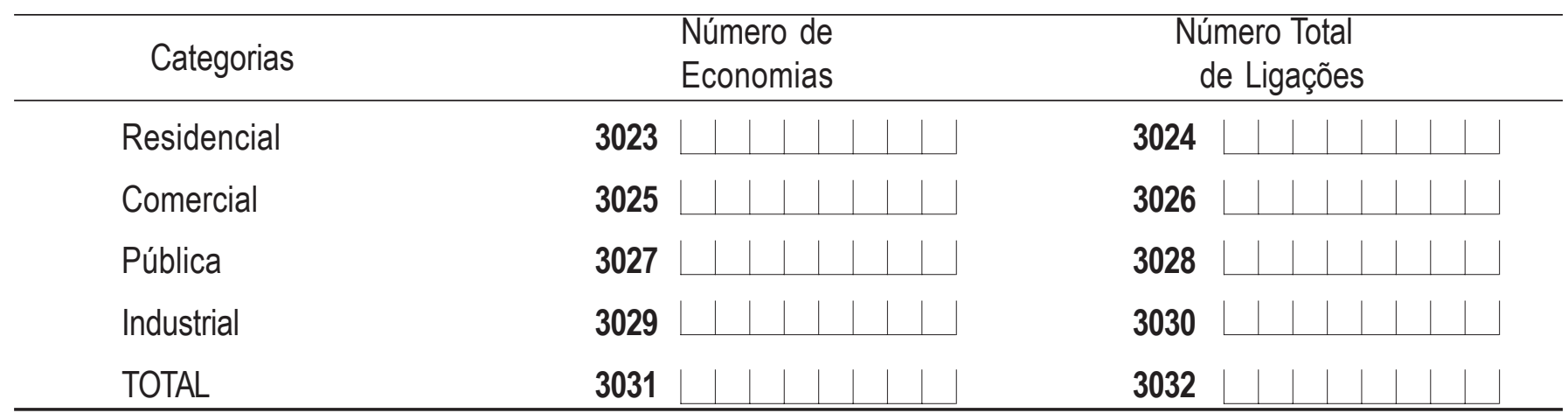


IDU

COMPLEMENTAÇÃO DAS INFORMAÇÕES 


\section{SEAD}

Fundação Sistema Estadual de Análise de Dados www.seade.gov.br 